\title{
DNA damage induces two distinct modes of cell death in ovarian carcinomas
}

\author{
H Vakifahmetoglu', M Olsson ${ }^{1}$, C Tamm ${ }^{1}$, N Heidari ${ }^{1}$, S Orrenius ${ }^{1}$ and B Zhivotovsky ${ }^{*, 1}$
}

Activation of $\mathrm{p} 53$ by cellular stress may lead to either cell cycle arrest or apoptotic cell death. Restrictions in a cell's ability to halt the cell cycle might, in turn, cause mitotic catastrophe, a delayed type of cell death with distinct morphological features. Here, we have investigated the contribution of p53 and caspase-2 to apoptotic cell death and mitotic catastrophe in cisplatin-treated ovarian carcinoma cell lines. We report that both functional p53 and caspase-2 were required for the apoptotic response, which was preceded by translocation of nuclear caspase-2 to the cytoplasm. In the absence of functional p53, cisplatin treatment resulted in caspase-2-independent mitotic catastrophe followed by necrosis. In these cells, apoptotic functions could be restored by transient expression of wt p53. Hence, p53 appeared to act as a switch between apoptosis and mitotic catastrophe followed by necrosis-like lysis in this experimental model. Further, we show that inhibition of Chk2, and/or 14-3-3 $\sigma$ deficiency, sensitized cells to undergo mitotic catastrophe upon treatment with DNA-damaging agents. However, apoptotic cell death seemed to be the final outcome of this process. Thus, we hypothesize that the final mode of cell death triggered by DNA damage in ovarian carcinoma cells is determined by the profile of proteins involved in the regulation of the cell cycle, such as p53- and Chk2-related proteins.

Cell Death and Differentiation (2008) 15, 555-566; doi:10.1038/sj.cdd.4402286; published online 7 December 2007

In dividing cells, DNA damage caused by genotoxic insults results in the activation of cell cycle checkpoints followed by DNA repair to ensure the integrity of the transcribed genome. DNA repair processes are mediated by two major protein kinase pathways: the ataxia-telangiectasia mutated (ATM) through checkpoint kinase 2 (Chk2), and the ataxia-telangiectasia and Rad-3-related through Chk1. ${ }^{1}$ ATM-mediated phosphorylation regulates the activity of various proteins, including p53, Mdm2 and Chk1. Under normal conditions, the p53 level is low due to Mdm2-mediated ubiquitination and subsequent proteasomal degradation. Upon phosphorylation through ATM, p53 interaction with Mdm2 is inhibited, resulting in its stabilization. ${ }^{2}$ p53 is activated by stress and, depending on the severity of damage, it triggers either $\mathrm{G}_{1}$ or $\mathrm{G}_{2}$ arrest, mainly through transcriptional upregulation of p21 and/or 143-3 $\sigma \cdot{ }^{3-5}$ Alternatively, apoptosis might be initiated through the activation of pro-apoptotic genes, such as Bax, PUMA or Fas receptor. ${ }^{6,7}$ In addition, PIDD, p53 upregulated protein with a death domain, appears to be a crucial target gene in a signaling pathway that is initiated by p53 and leads to either activation of NFKB-dependent cell survival or apoptosis. The regulation of these alternate signaling pathways is dependent on the modulation of PIDD autoprocessing. Hence, a limited amount of DNA breaks leads to the formation of a NFKBactivating fragment of PIDD (PIDD-C), whereas more severe DNA damage triggers formation of PIDD-CC and a strong apoptotic response. ${ }^{8}$ The apoptotic pathway includes caspase-2, which is activated within the PIDDosome complex, ${ }^{9,10}$ and causes cytochrome $c$ release and caspase activation. ${ }^{11-13}$ Hence, PIDDosome-mediated caspase-2 activation might be an important link between DNA damage and the engagement of the mitochondria-mediated apoptotic pathway. ${ }^{10,14}$

Although p53 plays a central role in DNA damage-induced apoptosis, cells carrying p53 mutations can still die from DNA lesions. Delayed death, referred to as mitotic catastrophe, can occur in p53-deficient cells and was described as the main form of cell death induced by ionizing radiation. ${ }^{15}$ It can also be triggered by treatment with microtubule-damaging agents, various anticancer drugs and mitotic failure caused by defective cell cycle checkpoints. At present, commonly accepted definition of mitotic catastrophe is absent, although some reports suggest that it shares several biochemical hallmarks of apoptosis, in particular mitochondrial membrane permeabilization and caspase activation. ${ }^{16,17}$ In spite of these observations, important differences between the two cell death modalities have emerged. Hence, the morphology of mitotic catastrophe is different from apoptosis. It is characterized by multi-nucleated giant cells with the formation of nuclear envelopes around individual clusters of missegregated, uncondensed chromosomes, whereas apoptosis results in cytoplasmic shrinkage and chromatin condensation. Moreover, Bcl-2 overexpression or caspase inhibition fails to prevent mitotic catastrophe and the accumulation of giant multi-nucleated cells. ${ }^{18,19}$

Previously, we demonstrated a crucial role for p53 and caspase- 2 in the apoptotic response of colon carcinoma cells

\footnotetext{
${ }^{1}$ Division of Toxicology, Institute of Environmental Medicine, Karolinska Institutet, Stockholm, Sweden

${ }^{*}$ Corresponding author: B Zhivotovsky, Division of Toxicology, Institute of Environmental Medicine, Karolinska Institutet, Box 210, Stockholm SE-171 77, Sweden. Tel: + 468524875 88; Fax: + 4683290 41; E-mail: Boris.Zhivotovsky@ki.se

Keywords: apoptosis; caspase-2; DNA damage; mitotic catastrophe; ovarian cancer

Abbreviations: Chk1-2, checkpoint kinase; cisplatin, cis-diaminedichloro-platinum(II); DBH, debromohymenialdisine; 5-FU, 5-fluorouracil; FACS, fluorescenceactivated cell sorting; fmk, fluoromethyl ketone; PI, propidium iodide

Received 09.7.07; revised 08.10.07; accepted 30.10.07; Edited by A Villunger; published online 07.12.07
} 
to DNA-damaging drugs. ${ }^{14}$ Here, we focus on the contribution of p53 and caspase-2 to mitotic catastrophe and/or apoptosis in ovarian carcinoma cells treated with cis-diamminedichloroplatinum(II) (cisplatin). We show that both p53 and caspase-2 are required for apoptosis, and that nuclear caspase-2 is translocated to the cytosol during this process. In contrast, the absence of p53 leads to mitotic catastrophe followed by necrosis-like lysis. Caspase-2 does not involve in this process. Further, Chk2 inhibition in cells expressing p53 triggers mitotic catastrophe in response to DNA damage. However, at later time points these cells undergo apoptosis. Thus, we hypothesize that mitotic catastrophe is solely a morphological feature, and that the final mode of cell death triggered by DNA damage is determined by the profile of proteins involved in the regulation of the cell cycle, such as p53- and Chk2-related proteins.

\section{Results}

Cisplatin-induced cell death in ovarian cancer cells. The conventional treatment regimen for ovarian cancer is combination chemotherapy of a platinum-based drug with paclitaxel. ${ }^{20}$ First, we compared the susceptibility of ovarian carcinoma Caov-4 and SKOV-3 cell lines to treatment with three different drugs, 5-FU, staurosporin and cisplatin. Analysis of nuclear morphology revealed that Caov-4 and SKOV-3 cells responded differently to these treatments. $5-\mathrm{FU}$, which is an inducer of p53-dependent apoptosis in colon carcinomas, ${ }^{21}$ showed no effect on either cell line. Staurosporin induced time-dependent accumulation of condensed nuclei in both cell lines. Finally, treatment with the DNA crosslinking agent, cisplatin, for $48 \mathrm{~h}$ led to an increased number of condensed nuclei in Caov-4, but not in SKOV-3, cells (Figure 1a). A distinct difference in response to cisplatin between cell lines was confirmed by analyzing oligonucleosomal DNA fragmentation (Figure 1b). In addition, FACS analysis of PI-stained cells displayed accumulation of a discrete sub- $\mathrm{G}_{1}$ (apoptotic) population only in Caov- 4 cells $24 \mathrm{~h}$ after cisplatin exposure (data not shown). The viability of both cell lines was studied by FACS using annexin V/PI co-staining and demonstrated the accumulation of apoptotic (in Caov-4) and necrotic-like (in SKOV-3) cells after cisplatin treatment (Supplementary Figure S1A). The changes in nuclear morphology, analyzed by Hoechst staining, revealed that at $24 \mathrm{~h}$ of cisplatin treatment, the nuclei of SKOV-3 cells became significantly larger, and at $48 \mathrm{~h}$ multi-nucleated cells with decondensed chromatin appeared (Figure 1c). After $72 \mathrm{~h}$, many multinucleated giant cells with chromosome vesicles were observed, and at $96 \mathrm{~h}$ most of the cells had started to collapse and detach from the culture plate, indicative of necrosis-like lysis. In contrast, Caov-4 cells showed evidence of apoptosis with formation of pyknotic nuclei and appearance of apoptotic bodies (Figure 1c). Moreover, in comparison to Caov-4 cells, which accumulated in the $\mathrm{G}_{2} / \mathrm{M}$ phase of the cell cycle, SKOV-3 cells revealed predominant accumulation in the $S$ phase following cisplatin treatment (Figure 1d). These results indicate that the genotoxic response to cisplatin differs between ovarian cancer cell lines. Caov- 4 cells responded by arresting in the $\mathrm{G}_{2}$ phase of the cell cycle followed by apoptotic cell death, whereas SKOV-3 cells displayed characteristics of mitotic catastrophe followed by necrosis-like lysis after predominant accumulation in S phase.

Characteristics of cisplatin-induced apoptosis and mitotic catastrophe in ovarian cancer cells. Although it was suggested that mitotic catastrophe shares certain key molecular events with apoptosis, ${ }^{17}$ these two processes have been argued to be fundamentally different. ${ }^{18}$ We found a time-dependent processing of caspase-2, -3 and -9 and increase in their activities in Caov-4 cells but not in SKOV-3 cells (Figure $2 \mathrm{a}$ and $\mathrm{b}$ ). No caspase- 8 activity or processing was detected in either one of the cell lines. Further, a timedependent cleavage of PARP was observed following cisplatin treatment only in Caov-4 cells (Figure 2d).

Previously, we have demonstrated the importance of caspase-2 activation for cytochrome $c$ release and completion of apoptosis upon 5-FU-induced DNA damage in HCT116 colon carcinoma cells. ${ }^{14}$ To investigate whether the mitochondrial apoptotic pathway is also involved in cisplatininduced cell death, the release of cytochrome $c$ in Caov-4 and SKOV-3 cells was analyzed. As expected, cytochrome $c$ release was found in cisplatin-treated Caov-4, but not in SKOV-3, cells (Figure 2c). Taken together, these observations demonstrate that the intrinsic apoptotic pathway is crucial for the cell death process in cisplatin-treated Caov-4 cells; however, caspase activation was not required for cisplatin-induced mitotic catastrophe in SKOV-3 cells.

Caspase-2 functions as an initiator caspase and is released from the nucleus into the cytosol upon cisplatin treatment of Caov-4 cells. To investigate the role of caspase-2 in cisplatin-induced apoptosis, siRNA targeting of the caspase-2 mRNA was performed. In cells with reduced caspase-2 (Figure 3a), a decrease in cisplatininduced cytochrome $c$ release (Figure $3 b$ ), a reduction in both caspase- 3 and -9 activities and PARP cleavage were observed (Figure $3 c$ and $d$ ).

Analysis of subcellular localization of caspase-2 revealed that it is primarily a nuclear protein in both cell lines (Figure 4a). However, upon cisplatin treatment of Caov-4 cells, caspase-2 was translocated from the nucleus into the cytosol (Figure $4 \mathrm{a}$ and b). Such translocation was not detected in SKOV-3 cells, where caspase-2 remained in the nucleus also in treated cells. In contrast, caspase-2 was processed and translocated into the cytosol in staurosporintreated SKOV-3 cells, which undergo apoptosis upon such treatment (data not shown). To investigate the mechanism of caspase-2 translocation following cisplatin treatment, Caov-4 cells were incubated with the inhibitor of nuclear export leptomycin B, which, however, did not block caspase-2 translocation in treated cells (data not shown). A previous observation demonstrating the ability of caspase-2 to induce cytochrome $c$ release and apoptosis in the presence of leptomycin B are in accordance with our results. ${ }^{22}$ Taken together, these findings suggest a role for caspase-2 as an initiator caspase of critical importance for the apoptotic outcome of cisplatin treatment in Caov- 4 cells. Although the 


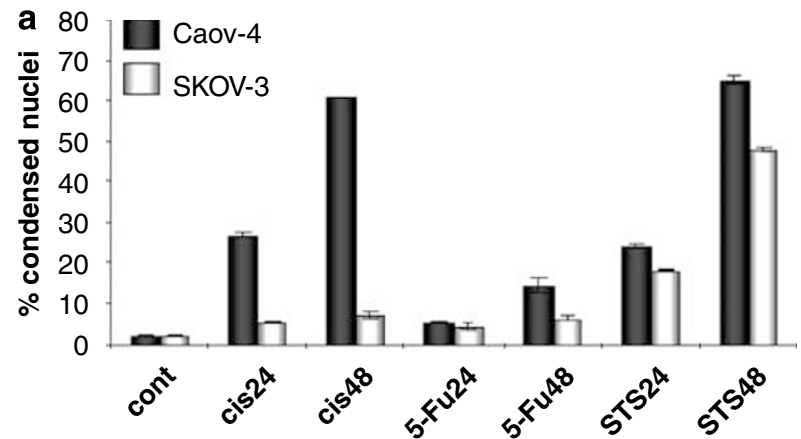

C

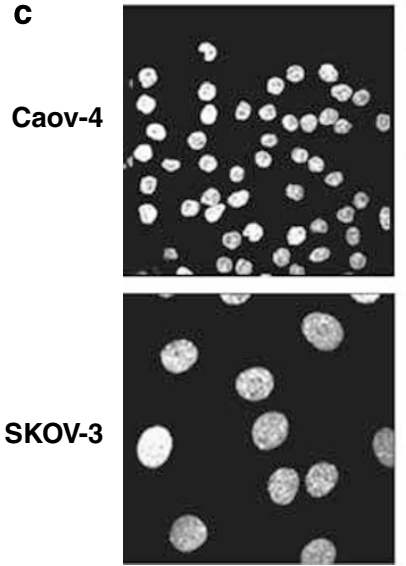

Control

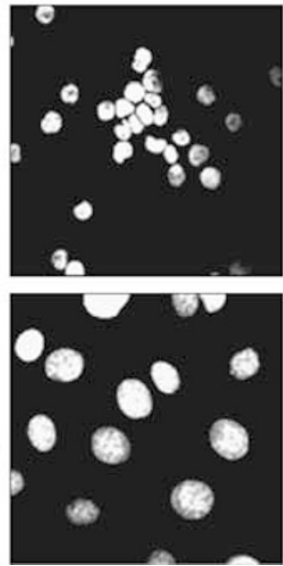

$24 \mathrm{hr}$
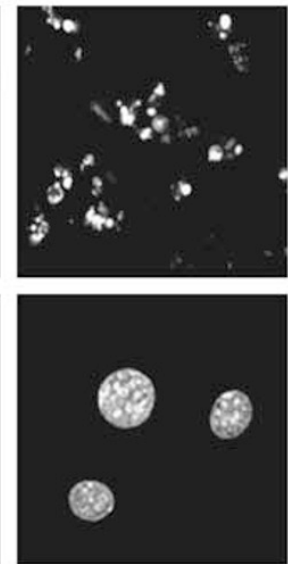

$48 \mathrm{hr}$

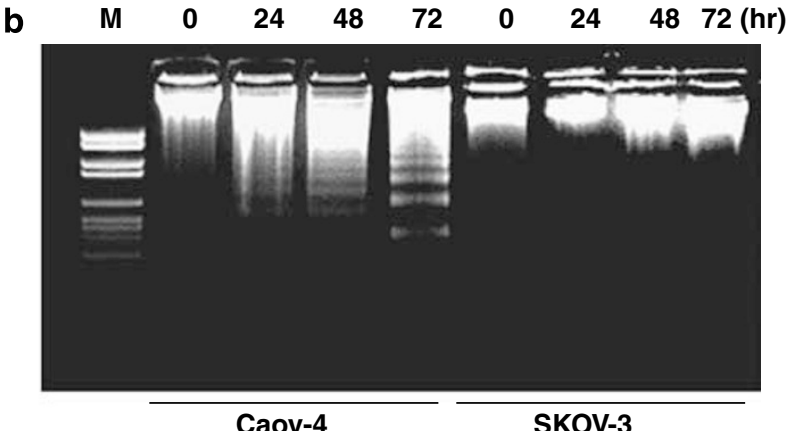

Caov-4
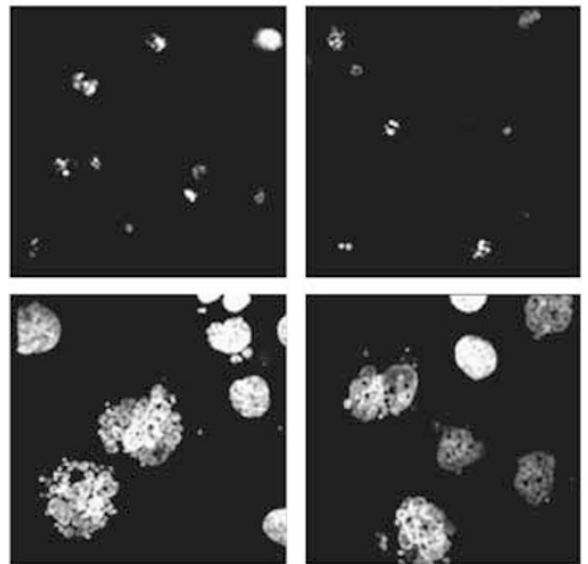

$72 \mathrm{hr}$

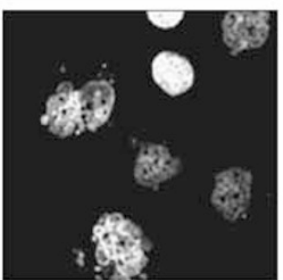

$96 \mathrm{hr}$

$\overline{20 \mu \mathrm{m}}$
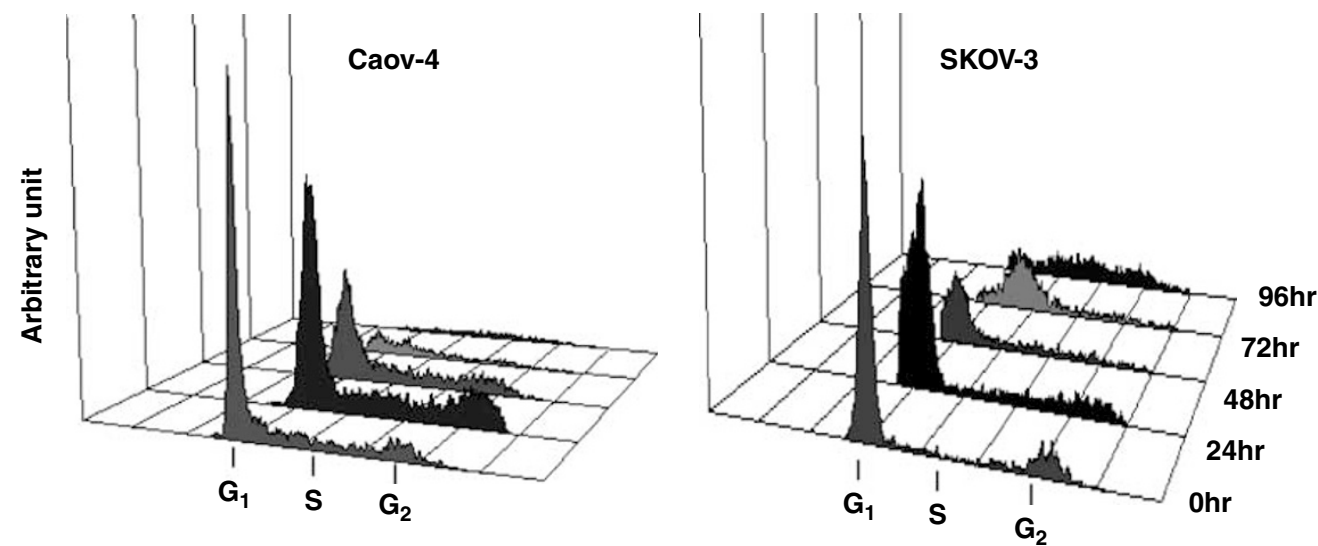

Cell cycle distribution

Figure 1 Cisplatin-induced cell death in ovarian cancer cells. (a) Percentage of Caov-4 and SKOV-3 cells with condensed or fragmented nuclei detected by Hoechst 33258 staining. At least 300 Hoechst-stained nuclei were counted per sample 24 and $48 \mathrm{~h}$ post-treatment with $33 \mu \mathrm{M}$ cisplatin, $375 \mu \mathrm{M} 5$-FU and $200 \mathrm{nM}$ staurosporin (STS). Results are mean \pm S.E. $(n=3)$. (b) Oligonucleosomal DNA fragmentation. Representative gel from three independent experiments is presented. Cells were harvested for analysis at the indicated time points after $33 \mu \mathrm{M}$ cisplatin treatment. M, marker. (c) Changes in the cellular morphologies of Caov-4 and SKOV-3 cells treated with $33 \mu \mathrm{M}$ cisplatin at the indicated time points. Representative images of cells stained with Hoechst obtained under fluorescence microscope. Bar $20 \mu \mathrm{m}$. (d) FACS analysis of the cell cycle distribution in Caov-4 and SKOV-3 cells following $33 \mu \mathrm{M}$ cisplatin treatment at the indicated time points

precise mechanism responsible for the export of nuclear caspase-2 to the cytosol is still unknown, it appears that such translocation might be a crucial event in apoptosis.

Caspase-2 is not required for cisplatin-induced mitotic catastrophe in SKOV-3 cells. Hence, our results suggest that cisplatin treatment of SKOV-3 cells results in mitotic catastrophe without requirement of caspase processing or activation. However, to investigate a possible involvement of pro-caspase-2 in mitotic catastrophe via interaction with other proteins, the level of caspase-2 in SKOV-3 cells was suppressed by siRNA transfection (Figure $5 \mathrm{a}$ and b). Using 
a
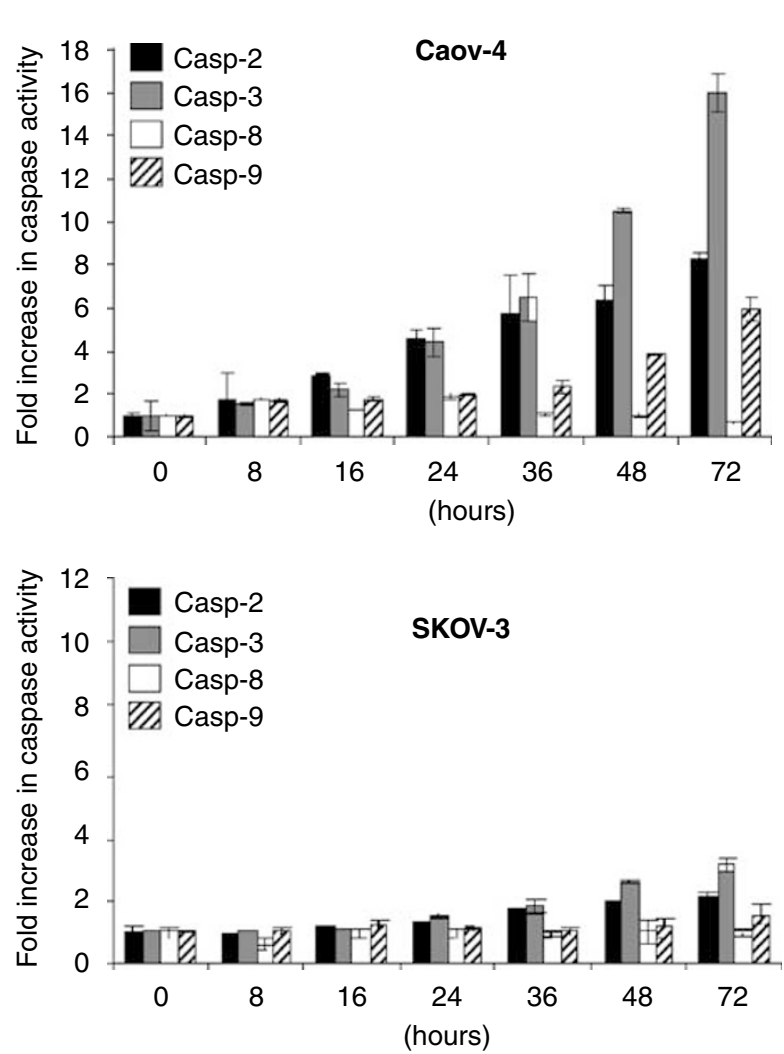

b
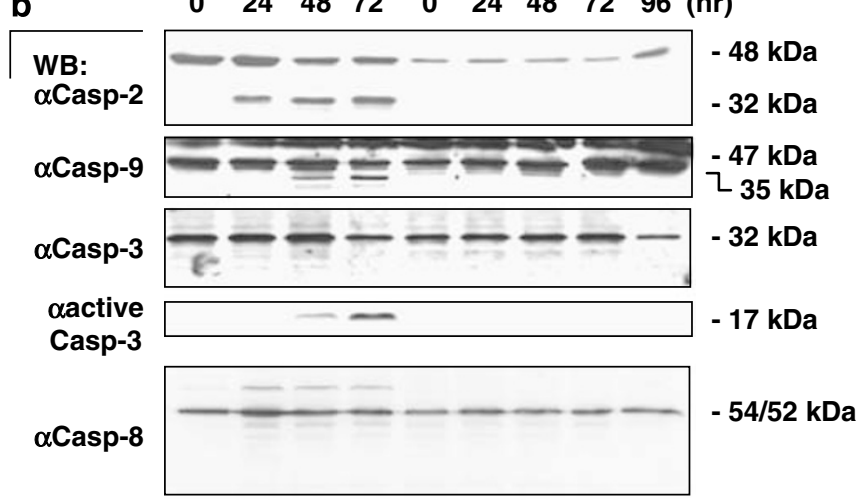

$\alpha G 3 P D H$

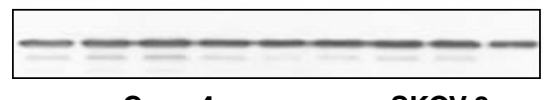

$-37 \mathrm{kDa}$

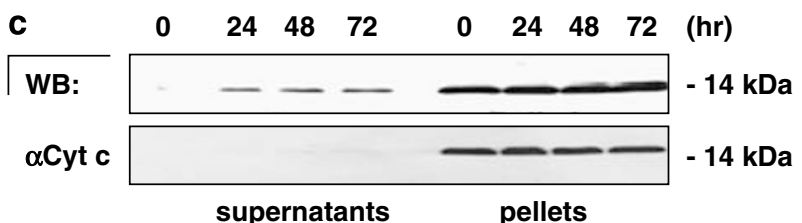

d

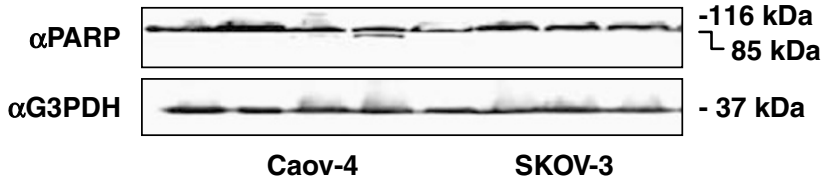

Figure 2 Characteristics of cisplatin-induced apoptosis and mitotic catastrophe in ovarian carcinomas. Caov-4 and SKOV-3 cells $\left(10^{6}\right)$ treated with $33 \mu \mathrm{M}$ cisplatin were harvested at the indicated time points. (a) Enzyme activity was monitored by the release of AMC from VDVAD-AMC, fold increase in caspase-2 activity; DEVD-AMC, fold increase in caspase-3-like activity; IETD-AMC, fold increase in caspase-8 activity and LEHD-AMC, fold increase in caspase- 9 activity. Results are mean \pm S.E. $(n=3$ ). (b) Western blots of caspase-2, $-3,-9,-8$ and active caspase-3 from untreated or cisplatin-treated Caov-4 and SKOV-3 cell lysates (100 $\mu \mathrm{g}$ ). (c) Immunoblots showing the differences in cytochrome $c$ distribution between mitochondria (pellets) and cytosol (supernatants) fractions in Caov-4 (upper panel) and SKOV-3 cells (lower panel) after cisplatin treatment at the indicated time points. (d) Cleavage of PARP in Caov-4 and SKOV-3 cells, following cisplatin treatment up to $72 \mathrm{~h}$. Blots were re-probed for G3PDH to confirm an equal loading of the samples

confocal microscopy, appearance of the mitotic catastrophe phenotype was still detected upon treatment of these cells (Figure $5 \mathrm{~b}$ ), indicating that caspase-2 is not required for cisplatin-induced mitotic catastrophe.

Functional p53 is required for cisplatin-mediated apoptosis in SKOV-3 cells. p53 is mutated in both cell lines employed in our study. In Caov-4 cells, p53 is expressed but carries a point mutation in codon 147. In SKOV-3 cells, deletion of a single nucleotide at position 267 (codon 90) blocks p53 protein expression. ${ }^{23}$ Thus, the lack of caspase-2 activation following cisplatin treatment in SKOV-3 cells might be a consequence of the lack of p53. In Caov-4 cells, immunoblotting, immunostaining and RT-PCR analysis provided evidence for p53 protein accumulation upon cisplatin treatment (Figure 6a-c). In contrast, there was no detectable p53 protein in SKOV-3 cells, irrespective of treatment (Figure 6a-c). Next, we analyzed whether cisplatin influenced p21 and PIDD expression in either cell line. The presence of $p 53$ in treated Caov- 4 cells generated increased amount of p21 (Figure 6a), whereas only a minor increase in PIDD was detected at both the protein and the
mRNA levels $24 \mathrm{~h}$ after treatment (Figure 6a and c). Notably, a time-dependent accumulation of a band corresponding to the 37-kDa cleavage fragment PIDD-CC of PIDD was found in Caov-4 cells. This band was not detected in SKOV-3 cells, which, however, demonstrated the appearance of the $51-\mathrm{kDa}$ fragment, PIDD-C (Figure 6a). Further, the importance of p53 for cisplatin-induced killing of SKOV-3 cells was demonstrated by transient overexpression of this protein. The presence of functional p53 in cisplatin-treated SKOV-3 cells led to processing of caspase-2 and -3 (Figure 7a). Moreover, in cisplatin-treated p53-overexpressing SKOV-3 cells, translocation of caspase-2 from the nucleus to the cytosol was observed (Supplementary Figure S2). In addition, treatment of these cells with cisplatin for up to $72 \mathrm{~h}$ resulted in apoptotic nuclear morphology and formation of apoptotic bodies (Figure 7b). These data demonstrate that p53 transduction markedly enhanced the sensitivity of SKOV-3 cells to cisplatin-induced apoptosis, and suggest a role for p53 as a negative regulator of mitotic catastrophe.

DNA damage triggers mitotic catastrophe in p53deficient Caov-4 cells. To further elucidate the role of p53 


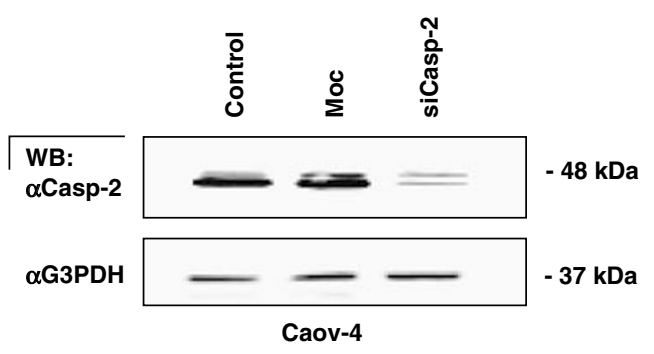

C

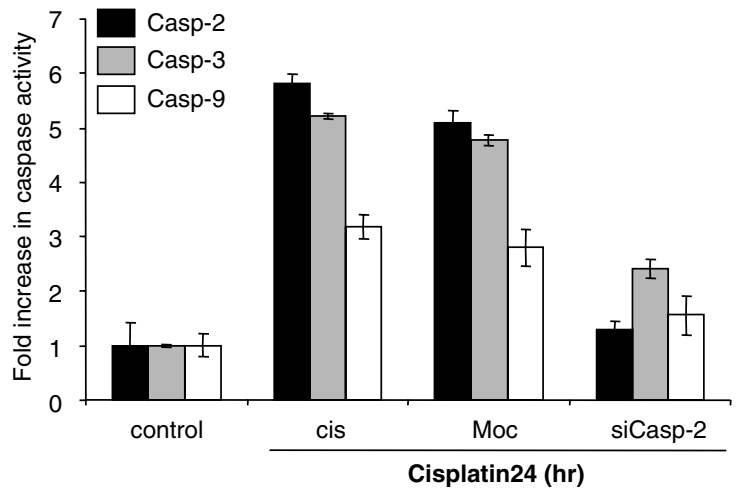

b
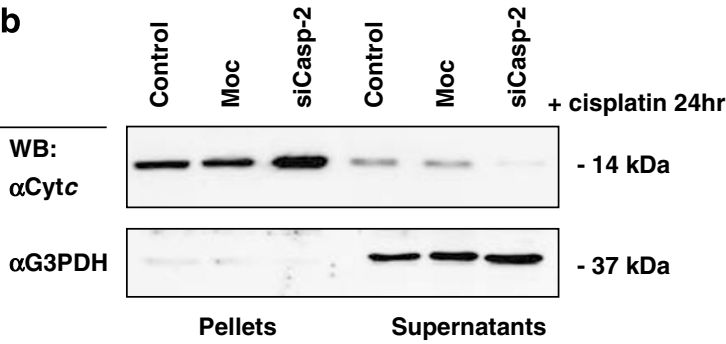

d

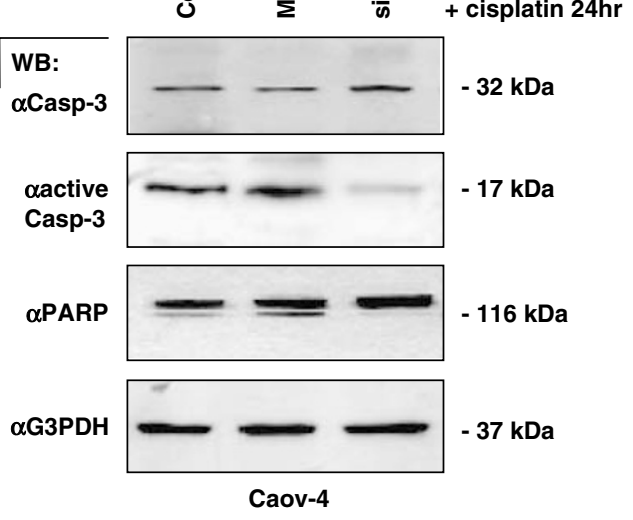

Figure 3 siRNA silencing of pro-caspase-2 inhibits cisplatin-induced apoptosis in Caov-4 cells. Caov-4 cells were cultured and transfected with caspase-2 siRNA for $48 \mathrm{~h}$ prior to cisplatin treatment. Cell lysates were harvested $24 \mathrm{~h}$ post-treatment and analyzed by western blot. Moc, scramble siRNA used as a control. (a) siRNA silencing of caspase-2 $48 \mathrm{~h}$ post-transfection. Downregulation estimated as $80 \%$. (b) Distribution of cytochrome $c$ between mitochondria (pellets) and cytosol (supernatants) fractions in siRNA caspase-2-transfected Caov-4 cells upon $24 \mathrm{~h}$ cisplatin treatment. (c) VDVAD-AMC, fold increase in caspase-2 activity; DEVD-AMC, fold increase in caspase-3-like activity and LEHD-AMC, fold increase in caspase- 9 activity following $24 \mathrm{~h}$ cisplatin treatment in siRNA caspase-2-transfected Caov- 4 cells. Results are mean \pm S.E. ( $n=3$ ). (d) Western blots of pro- and cleaved caspase-3 and PARP. G3PDH was used as a control for equal loading of the samples

in apoptosis and mitotic catastrophe, the level of p53 protein was suppressed in Caov-4 cells by siRNA transfection (Figure 8a). The changes in nuclear morphology following cisplatin treatment were then investigated. In contrast to control cells, the downregulation of p53 in Caov-4 cells led to mitotic catastrophe upon treatment (Figure $8 \mathrm{~b}$ ). At $48 \mathrm{~h}$, the nuclei of treated cells became significantly larger, and at $72 \mathrm{~h}$ multi-nucleated giant cells with chromosome vesicles containing decondensed chromatin appeared. After $96 \mathrm{~h}$, most of the cells collapsed, lysed and detached from the culture plate (data not shown). These observations demonstrate that DNA damage triggers mitotic catastrophe of p53-deficient Caov-4 cells, like it does in p53-deficient SKOV-3 cells. Hence, p53 appears to act as a switch between apoptosis and necrosis following mitotic catastrophe in ovarian cancer cells, suggesting that functional p53 is essential for initiation of cisplatin-mediated apoptosis.

Chk2 inhibition induces mitotic catastrophe in Caov-4 cells. Studies aiming to elucidate the process of mitotic catastrophe in molecular terms are based mostly on experiments performed on HCT116 colon carcinoma cells treated with doxorubicin. ${ }^{5,24}$ In these studies, the inhibition of Chk2, or the absence of the cell cycle regulator 14-3-3 $\sigma$, was found to facilitate translocation of the cyclin-dependent kinase 1/cyclin B complex to the nucleus, thereby preventing $G_{2}$ arrest and triggering mitotic catastrophe in response to DNA damage. To investigate whether Chk2 inhibition also triggers mitotic catastrophe in response to cisplatin, Caov-4 cells were pretreated with the Chk2 inhibitor, debromohymenialdisine $(\mathrm{DBH})$, and the changes in nuclear morphology following cisplatin exposure were observed. In contrast to cells treated with either $\mathrm{DBH}$ or cisplatin alone for up to $72 \mathrm{~h}$, the combination of both chemicals led to formation of multi-nucleated giant cells with chromosome vesicles, indicative of mitotic catastrophe (Figure 8c). However, apoptotic bodies with condensed chromatin appeared when the cells were exposed to cisplatin for longer time periods. Hence, at $96 \mathrm{~h}$ almost all cells displayed appearance of pyknotic nuclei. It was previously reported that the inactivation of Chk2 can sensitize cell to mitotic catastrophe in the presence of DNA-damaging agents. ${ }^{24}$ However, although our experiments confirmed this, DBH-pretreated Caov-4 cells still died by apoptosis after exposure to cisplatin.

As mentioned above, treatment of $14-3-3 \sigma^{-1-}$ HCT116 cells with doxorubicin leads to mitotic catastrophe, ${ }^{5}$ in a process that also involves caspase activation and chromatin condensation. ${ }^{24}$ In light of our findings, it was of interest to investigate the effect of doxorubicin in 14-3-3 $\sigma^{-1-}$ HCT116 cells at later time points. Treatment with doxorubicin led to p53 
a
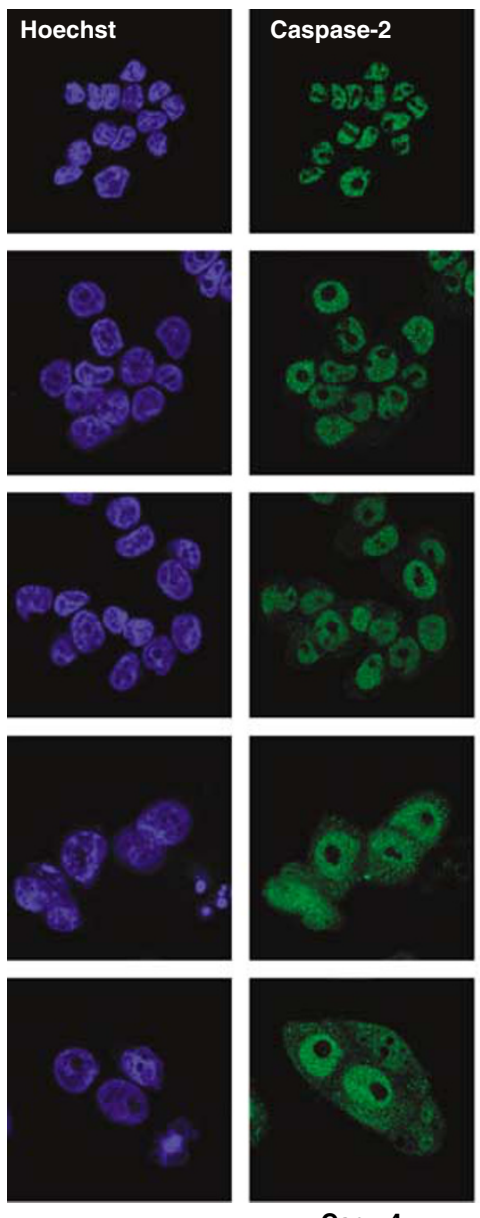

Caov-4
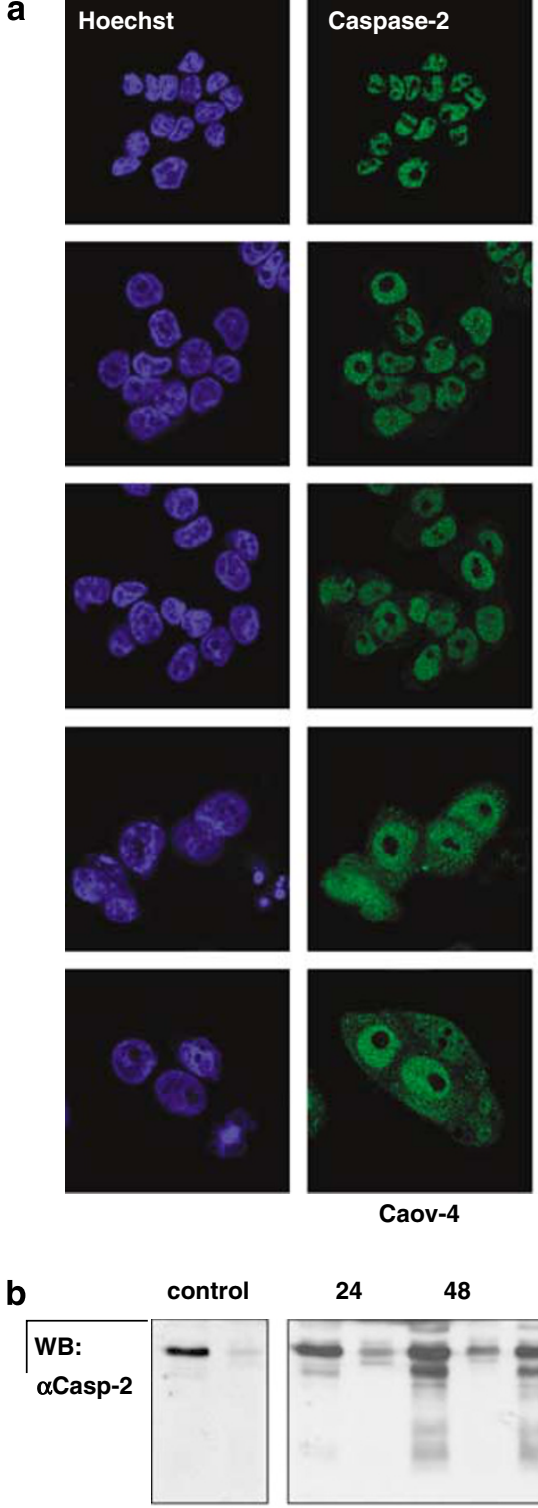

$\alpha$ G3PDH

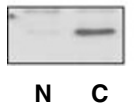

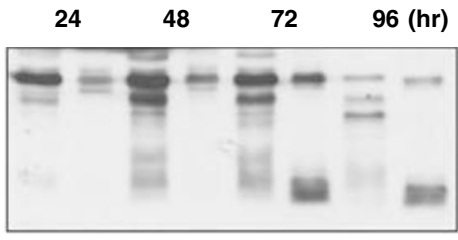
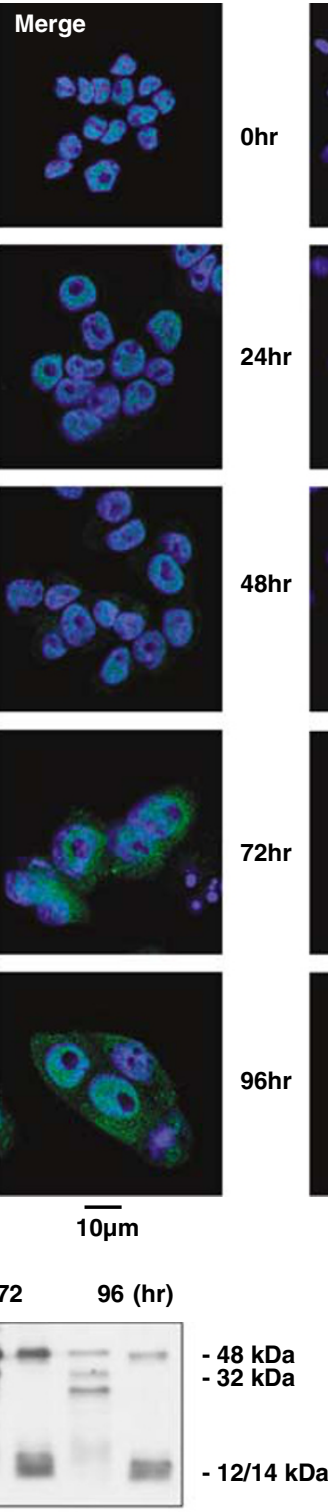

Ohr

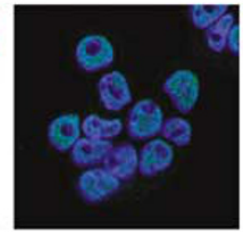

$24 \mathrm{hr}$

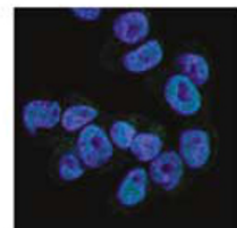

$48 \mathrm{hr}$
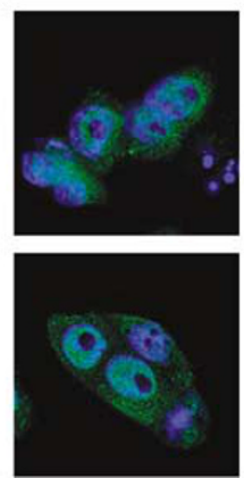

$\overline{10 \mu \mathrm{m}}$

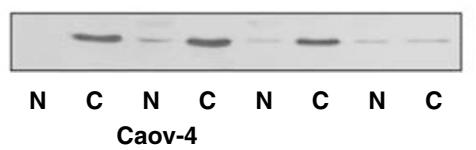

- 37 kDa
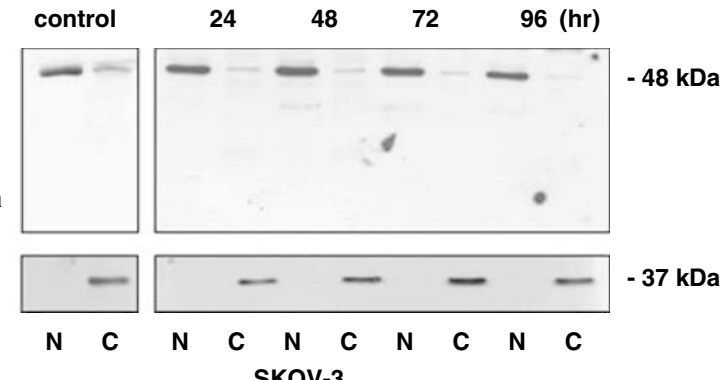

Figure 4 Cellular localization of caspase-2 in Caov-4 and SKOV-3 cells. (a) Caov-4 and SKOV-3 cells, either untreated or cisplatin-treated for $96 \mathrm{~h}$, were stained using antibodies directed against caspase-2 (green). Co-staining of nuclei was performed using Hoechst (blue). Representative images of cells were obtained under fluorescence microscope. Bar: $10 \mu \mathrm{m}$ for Caov-4 and $20 \mu \mathrm{m}$ for SKOV-3 cells. (b) Immunoblots showing the differences in caspase-2 distribution between nuclear (N) and cytosol (C) fractions in Caov-4 and SKOV-3 cells following cisplatin treatment at the indicated time points. G3PDH was used as a control for equal loading of the samples

accumulation, as documented by immunoblotting and RTPCR analysis (Figure 6c, and data not shown) and, in line with previous observations, to processing of caspase-2 (Figure 9a). This was significantly reduced in the presence of z-VDVAD-fmk. In addition, a time-dependent increase in both caspase-2 and -3-like activities upon treatment with doxorubicin was demonstrated (Figure 9b). The changes in nuclear morphology following doxorubicin treatment revealed the appearance of multi-nucleated cells with chromosome vesicles at $24 \mathrm{~h}$ (Figure 9c). However, $48 \mathrm{~h}$ after treatment cells started to display chromatin condensation, and at $72 \mathrm{~h}$ apoptotic bodies with condensed nuclei were observed in most cells. These data are in agreement with our observations using Chk2-inhibited Caov-4 cells and indicate that inhibition and/or downregulation of Chk2- and Chk-2-related proteins sensitize cells to undergo mitotic catastrophe upon treatment with DNA-damaging agents. Nevertheless, apoptotic cell death seems to be the final outcome of this process. 


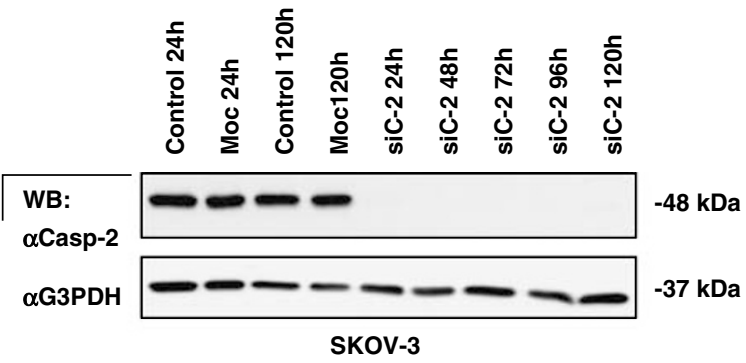

b
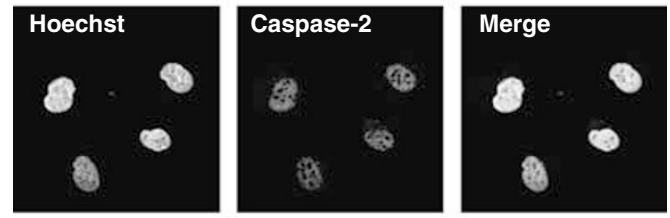

Moc
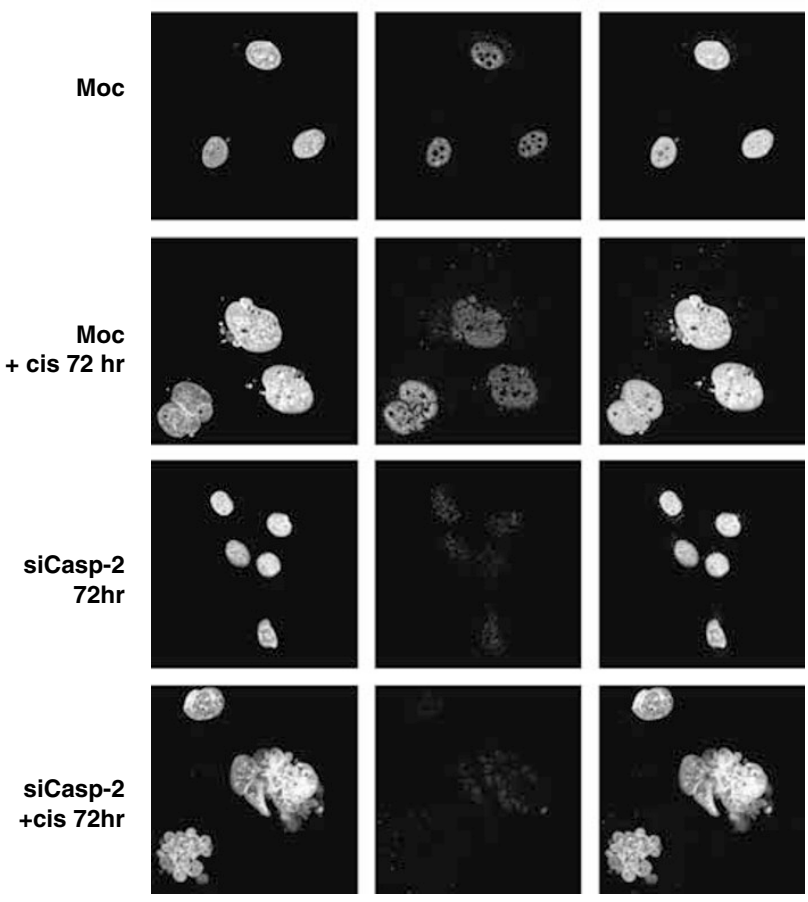

SKOV-3

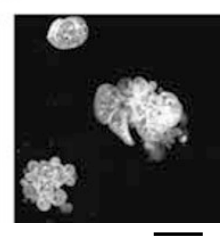

$20 \mu \mathrm{m}$

Figure 5 Caspase-2 is not required for cisplatin-induced mitotic catastrophe. SKOV-3 cells were cultured and transfected with caspase-2 siRNA. Cell lysates were harvested at the indicated time points post-treatment and analyzed by Western blot. (a) siRNA silencing of caspase-2 at the indicated time points. Moc, scramble siRNA used as a control. Downregulation was complete (100\%). (b) Caspase-2 siRNA-transfected SKOV-3 cells were treated with or without cisplatin up to $72 \mathrm{~h}$ ( $24 \mathrm{~h}$ post-transfection). Co-staining of nuclei was performed using Hoechst. Representative images of cells stained with caspase-2 were obtained under fluorescence microscope. Bar $20 \mu \mathrm{m}$

\section{Discussion}

For many human cancers, chemoresistance is a therapeutic problem that severely limits a successful outcome. This is particularly true for ovarian cancer, in which the development of chemoresistance is common. The preferred treatment regimen for ovarian cancer is a combination chemotherapy of platinum-based drug with paclitaxel. ${ }^{20}$ We found that ovarian cancer cells differ in their response to cisplatin, which involves either apoptosis or necrosis following mitotic catastrophe. Cell death kinetics was monitored in two cell lines between 24 and $96 \mathrm{~h}$ after treatment. Apoptosis was first detected in Caov-4 cells at $24 \mathrm{~h}$ by DNA fragmentation and chromatin condensation, with formation of apoptotic bodies seen at $48 \mathrm{~h}$. In contrast, cisplatin-treated SKOV-3 cells displayed an entirely different nuclear morphology with the appearance of micronuclei with decondensed and segregated chromosomes enclosed in nuclear envelopes (likely arising through abnormal mitosis). This morphology has previously been reported to result from mitotic catastrophe. ${ }^{18}$ However, later on these cells died by necrosis-like lysis.

It has been debated whether mitotic catastrophe results in cell death via activation of caspase-dependent or -independent mechanisms. For example, in the model of Chk2inhibited syncytia, pre-mitochondrial activation of apical caspases in general, and of caspase-2 in particular, was detected in metaphase-associated mitotic catastrophe. ${ }^{17}$ However, in our model, there was a time-dependent increase in caspase activation only in apoptotic Caov-4 cells, whereas cisplatin-induced mitotic catastrophe developed without the involvement of caspase activation in SKOV-3 cells. In accordance with a previous study, ${ }^{25}$ this observation indicates that caspases are not mandatory for mitotic cell death. This conclusion is also supported by our finding that caspase-2 silencing did not prevent mitotic catastrophe.

Caspase-2 is characterized by a unique intracellular distribution. This enzyme has been found in the cytosol, as well as in the Golgi complex and the nucleus. ${ }^{26,27}$ Although mitochondrial caspase-2 translocation was described in Birc6-deficient murine embryonic fibroblasts, a recent investigation using a set of antibodies raised to different epitopes of caspase- 2 failed to provide evidence for its presence in the mitochondria. ${ }^{28,29}$ Importantly, pro-caspase-2 is the only procaspase present constitutively in the nucleus. ${ }^{27,30}$ Consistent with these studies, a primarily nuclear localization of procaspase-2 was found in both Caov-4 and SKOV-3 cells (Figure 4). Moreover, we show for the first time a nuclearcytoplasmic translocation of constitutive caspase-2 during apoptosis. Whether caspase-2 activation takes place within the nucleus, and is required for its translocation, or whether translocation precedes activation is still unclear.

It has been suggested that the presence of functional p53 in ovarian cancer cells enhances their sensitivity to radiation, but the correlation between their p53 status and susceptibility to platinum treatment has been unclear. ${ }^{31,32}$ We found a strong correlation between the expression of p53 and the sensitivity to cisplatin-induced apoptosis. Caov-4 cells responded to cisplatin treatment by elevated p53 expression followed by Bid cleavage and Bax activation (Supplementary Figure S1B and C). In addition, in Caov-4 cells the autoprocessing of PIDD was found to generate the PIDD-CC fragment, that is strongly correlated with the apoptotic response of cells, in which caspase-2 activation is a prerequisite for apoptosis. ${ }^{8}$ In SKOV-3 cells, PIDD was found to autoprocess only into the PIDD-C fragment, which has been associated with NF-кBdependent cell survival. Recent results demonstrate the inducible assembly of a protein complex consisting of caspase-2, TRAF2 and RIP1 that activates NF- $\mathrm{B}$ and $\mathrm{p} 38$ 


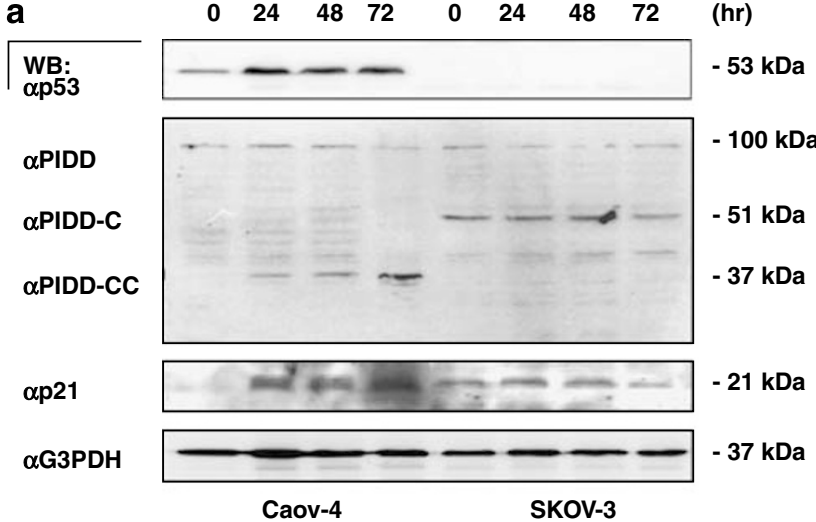

b

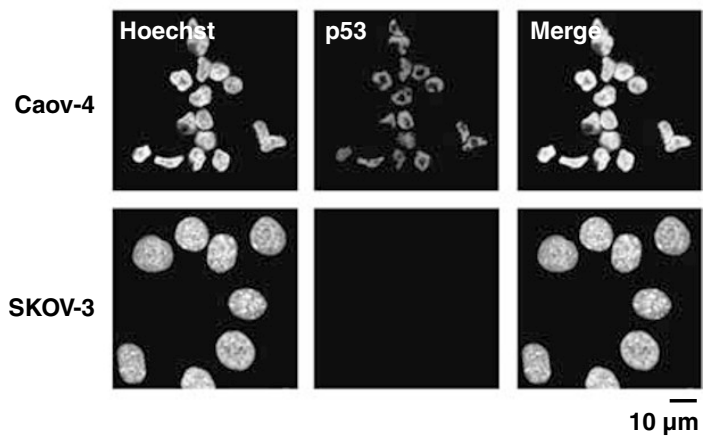

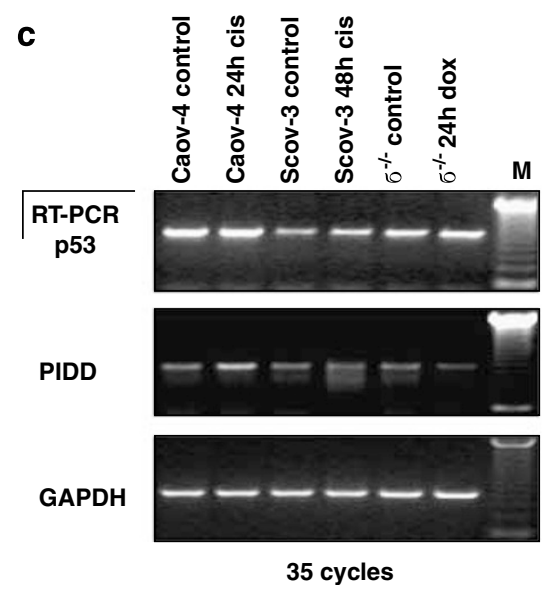

Figure 6 The p53 and p53-related protein status in Caov-4 and SKOV-3 cells. Untreated or cisplatin-treated Caov-4 and SKOV-3 cells $\left(10^{6}\right)$ were harvested at the indicated time points and analyzed by Western blot. (a) Immunoblots of p53, PIDD and p21 in Caov-4 and SKOV-3 cell lysates (100 $\mu$ g) at the indicated time points. G3PDH was used as a control for equal loading of the samples. (b) Untreated Caov-4 and SKOV-3 cells were stained using antibodies directed against p53. Co-staining of nuclei was performed using Hoechst. Representative images of cells were obtained under fluorescence microscope. (c) RT-PCR analysis for GAPDH, p53 and PIDD in Caov-4, SKOV-3 and 14-3-3 $\sigma^{-l-}$ HCT116 cells, treated with cisplatin or doxorubicin, respectively, at the indicated time points. Bar $10 \mu \mathrm{m}$

MAPK through the caspase recruitment domain of caspase-2 independently of its proteolytic activity. ${ }^{33}$ However, it is unclear whether PIDD-C is also present in this complex and if these cells with active NF- $\kappa B$ undergo necrosis upon DNA damage.

Cisplatin is known to induce growth arrest in either the S- or the $\mathrm{G}_{2} / \mathrm{M}$-phase of the cell cycle. Indeed, cisplatin administration resulted in an accumulation of Caov- 4 cells in $\mathrm{G}_{2} / \mathrm{M}$ phase. Previously, it has been shown that p53 plays a critical role in the maintenance of the $\mathrm{G}_{2}$ checkpoint and in the prevention of premature entrance into mitosis after DNA damage. ${ }^{4,21}$ Moreover, failure of cells to arrest in the $\mathrm{G}_{2}$ phase in response to cytotoxic agents has been described as a consequence of the absence, downregulation, or inhibition of $\mathrm{G}_{2}$ checkpoint proteins, including p53, p21, Chk2 and 14-3-3- $\sigma \sigma^{4,5,34}$ Given that p53 or its related pathways are inactivated, abrogation of the $\mathrm{G}_{2}$ checkpoint leads to entrance of cells into premature mitosis. Cells suffering from abnormal mitosis fail to segregate their chromatin and do not divide. However, they are not prevented from re-entering the cell cycle. Instead, after aberrant mitosis and mitotic exit, cells proceed into S-phase-like growth arrest. A similar S-phase arrest was observed in SKOV-3 cells.
The results of this study clearly show a critical role for p53 in the regulation of mitotic catastrophe in response to DNA damage (Figure 10). Several reports indicate that not only the absence of p53 but also the inhibition or downregulation of Chk2-related proteins can enhance the frequency of catastrophic mitoses. ${ }^{4,5,34}$ However, in contrast to these studies, we show that doxorubicin-induced mitotic catastrophe in 14-3$3 \sigma^{-1-}$ HCT116 cells, as well as in Chk2-inhibited Caov- 4 cells, is followed by apoptosis at later time points (Figure 10). Although functional p53 is present in $14-3-3 \sigma^{-1-}$ HCT116 cells, it seems that these cells are delayed with respect to activation of the apoptotic program. Our findings are supported by the observations demonstrating that cells that escape $G_{2}$ arrest and enter mitosis initially respond to abnormal mitosis through a p53-independent pathway. ${ }^{35}$ This pathway has been shown to activate a checkpoint located in the metaphase-anaphase transition, and whose function is to synchronize mitosis with spindle formation. Eventually, cells can escape from this block by mitotic slippage. ${ }^{36}$ Moreover, after prolonged mitotic arrest, mitotic slippage can induce cell death by a p53-dependent pathway in which p53 target genes trigger apoptosis. ${ }^{37,38}$ Our results suggest that the increased p53 expression, followed by caspase-2 activation, occurs subsequently to the morphological 
a

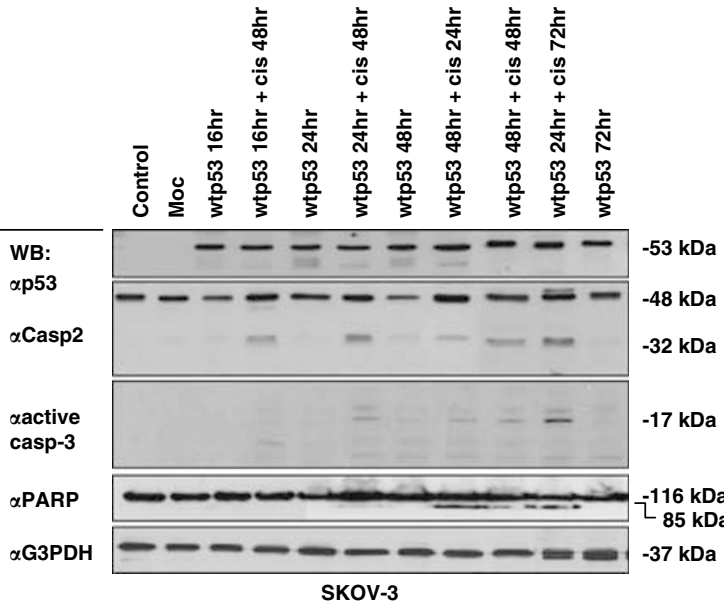

b
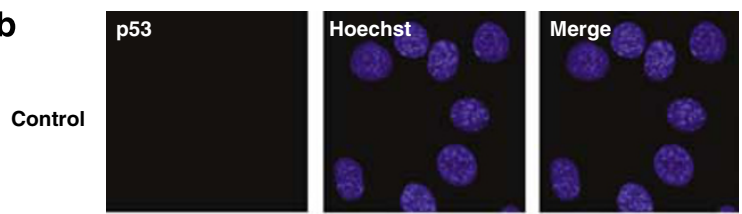

Moc
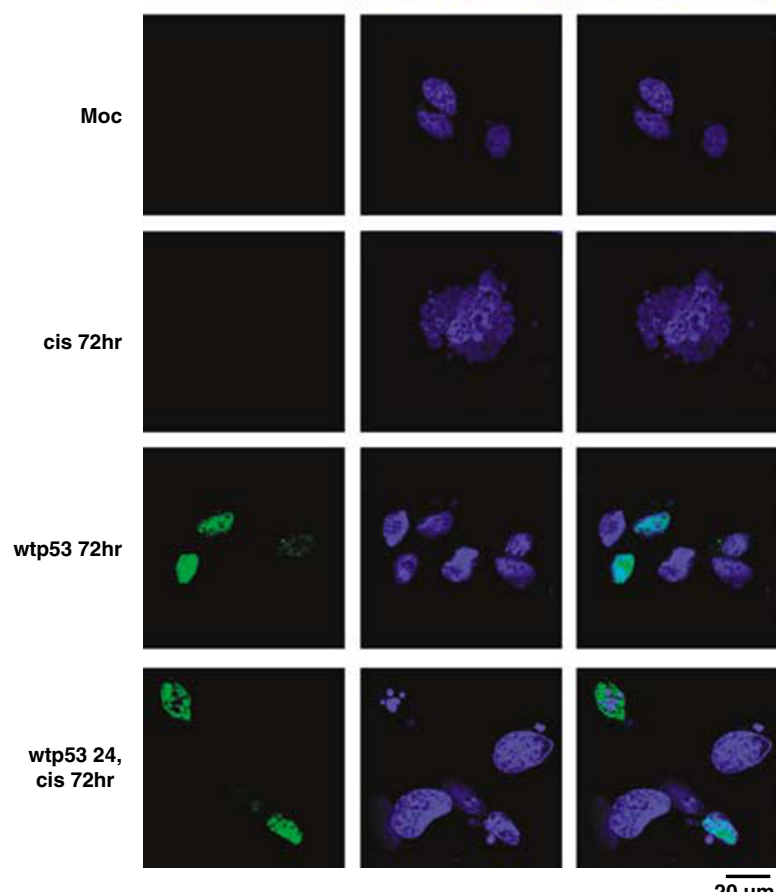

Figure 7 Functional p53 is crucial for cisplatin-mediated apoptosis in SKOV-3 cells. SKOV-3 cells $\left(10^{5}\right)$ were transfected with either vehicle- or wt p53-vector for $16,24,48$ and $72 \mathrm{~h}$ prior to 24,48 or $72 \mathrm{~h}$ cisplatin treatment and harvested. (a) Cell lysates $(100 \mu \mathrm{g})$ were analyzed by Western blot. Immunoblots of p53, caspase-2 and active caspase-3 are shown. G3PDH was used as a control for equal loading of the samples. (b) Changes in the nuclear morphology in untransfected, moc or wt p53-transfected SKOV-3 cells treated with or without cisplatin up to $72 \mathrm{~h}(24 \mathrm{~h}$ posttransfection). Cells were stained using antibodies directed to p53 (green). Costaining of nuclei was performed using Hoechst (blue). Representative pictures of cells were obtained under fluorescence microscope. Bar $20 \mu \mathrm{m}$

changes characteristic of mitotic catastrophe. This indicates that DNA damage-induced mitotic catastrophe precedes apoptosis, which is delayed due to a primary mitotic arrest.
Although there is no generally accepted definition of mitotic catastrophe, it has been referred to as a mode of cell death that occurs during, or shortly after, dysregulated or failed mitosis, and which is thought to be fundamentally different from apoptosis. ${ }^{18}$ However, despite its distinctive morphology, mitotic catastrophe may represent a pre-stage of apoptosis. This suggestion is based on studies indicating that apoptosis might follow, rather than precede, mitotic catastrophe. ${ }^{39-41}$ Apoptosis, however, is not always required for the lethal effect of mitotic catastrophe, ${ }^{19}$ since abnormal mitosis can lead to cell death through both apoptosis and necrosis based on the molecular profile of the cells ${ }^{42,43}$ (Figure 10). Further studies are required for a better understanding of this relationship.

\section{Materials and Methods}

Cell culture. The human epithelial ovarian carcinoma cell lines, Caov-4 and SKOV-3, were cultured in RPMI 1640 complete medium supplemented with $10 \%$ (v/v) heat-inactivated fetal calf serum, $2 \%(\mathrm{w} / \mathrm{v})$ glutamine, $100 \mathrm{U} / \mathrm{ml}$ penicillin and $100 \mu \mathrm{g} / \mathrm{ml}$ streptomycin. The $14-3-3 \sigma^{-1-}$ HCT116 cells were cultured in McCoy's medium supplemented with $10 \%(\mathrm{v} / \mathrm{v})$ heat-inactivated fetal calf serum, $100 \mathrm{U} / \mathrm{ml}$ penicillin and $100 \mu \mathrm{g} / \mathrm{ml}$ streptomycin. Cells were grown in a humidified $5 \% \mathrm{CO}_{2}$ atmosphere at $37^{\circ} \mathrm{C}$ and maintained in a logarithmic growth phase for all experiments. Throughout the experiments, cells were treated with either $33 \mu \mathrm{M}$ cisplatin (Bristol-Meyers), $375 \mu \mathrm{M}$ 5-FU (Sigma-Aldrich, Saint Louis, MO, USA), $0.1 \mu \mathrm{M}$ staurosporine (Sigma-Aldrich) or $200 \mathrm{nM}$ doxorubicin (Farmitalia Carlo Erba, Spain) for the indicated time period. In selected samples, the irreversible caspase-2 inhibitor z-VDVAD-fmk (25 $\mu \mathrm{M})$ (Enzyme Systems Products, Livermore, CA, USA), and selective Chk2 inhibitor, DBH $(20 \mu \mathrm{M})$ (Alexis Biochemicals, San Diego, CA, USA) were added 1 and $24 \mathrm{~h}$, respectively, before treatment with chemotherapeutic drugs. The specific inhibitor of the nuclear export, leptomycin B (1 nM) (SigmaAldrich) was added simultaneously with the chemotherapeutic drug.

Plasmids. At $24 \mathrm{~h}$ after setting in culture dishes with fresh medium, SKOV-3 cells $\left(10^{5}\right)$ were transfected with plasmid encoding wild-type p53. Transfections were performed with LipofectAMINE PLUS (Invitrogen, San Diego, CA, USA) according to the manufacturer's protocol. As control, cells were transfected with an empty vector.

Hoechst staining and immunofluorescence. Cells seeded overnight on coverslips were fixed for $20 \mathrm{~min}$ in $4 \%$ paraformaldehyde on ice. Permeabilization and blocking of nonspecific binding of antibodies were performed by incubation of cells in PBS buffer containing $10 \mathrm{mM}$ HEPES, $3 \%$ BSA and $0.3 \%$ Triton X-100 at RT for 60 min. Incubations with primary $(1: 100)$ and secondary antibodies $(1: 200)$, diluted in PBS buffer, were performed at $4{ }^{\circ} \mathrm{C}$ overnight and at RT for $60 \mathrm{~min}$, respectively. Counterstaining of nuclei was carried out by a 10-min incubation with Hoechst $33342(1 \mu \mathrm{g} / \mathrm{ml}$ in PBS solution) at RT. Between all steps, cells were washed for $3 \times 10 \mathrm{~min}$ with PBS at RT. Stained sections were mounted using Vectashield $\mathrm{H}-1000$ (Vector Laboratories Inc.) and examined under a LSM 510 META confocal laser scanner microscope (Zeiss, Göttingen, Germany). Fluorescent secondary antibodies directed to mouse (Alexa 488), rabbit (Alexa 594) and rat (Alexa 647) were purchased from Molecular Probes (Leiden, The Netherlands). The number of apoptotic cells was measured by assessing the percentage of cells displaying fragmented or condensed nuclei. Approximately 300 nuclei were counted per sample.

DNA fragmentation. Cells $\left(2 \times 10^{6}\right)$ after treatment were washed in PBS and resuspended in $500 \mu \mathrm{l}$ lysis buffer (100 mM Tris- $\mathrm{HCl}$, pH 8.5, $5 \mathrm{mM}$ EDTA, $0.2 \mathrm{M}$ $\mathrm{NaCl}, 0.2 \% \mathrm{SDS}$ and $0.1 \mathrm{mg} / \mathrm{ml}$ proteinase $\mathrm{K}$ ). After overnight incubation, DNA was precipitated by adding an equal volume of isopropanol, and dissolved in $50 \mu \mathrm{lTE}$ buffer (10 mM Tris-HCl, pH 8.0, $1 \mathrm{mM}$ EDTA) containing $0.1 \mathrm{mg} / \mathrm{ml}$ RNase A, and incubated at $37^{\circ} \mathrm{C}$ for $30 \mathrm{~min}$ to degrade mRNA. DNA samples were mixed with $6 \times$ Loading Dye Solution (Fermentas), separated at $50 \mathrm{~mA}$ in a $2 \%$ agarose gels containing ethidium bromide and visualized by UV light. The DNA marker VI (Roche Diagnostics) served as a molecular marker. 


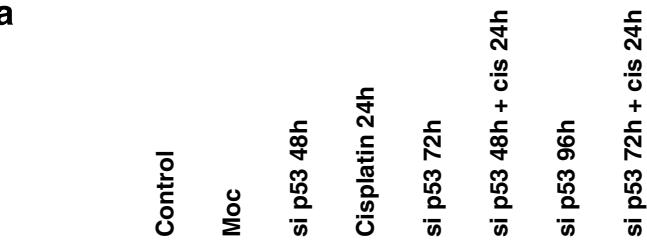

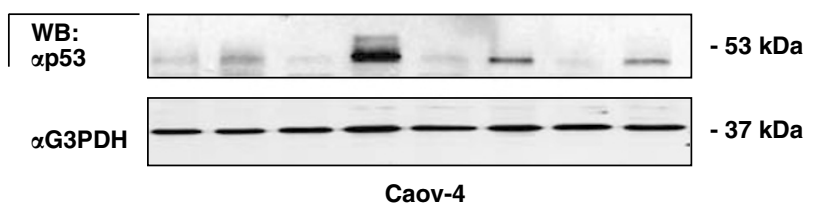

C
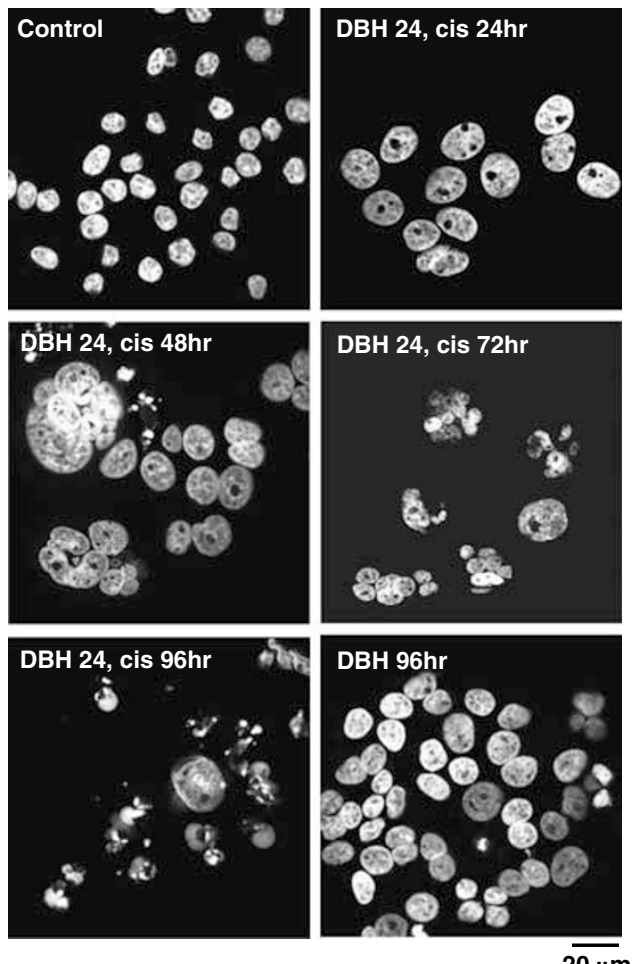

b
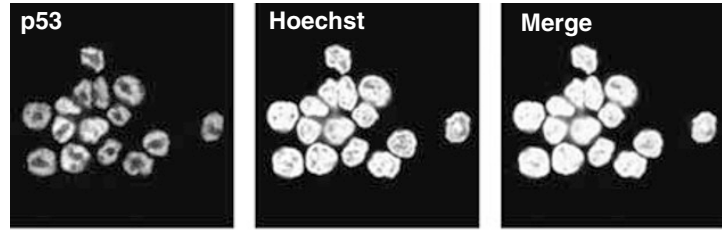

Moc
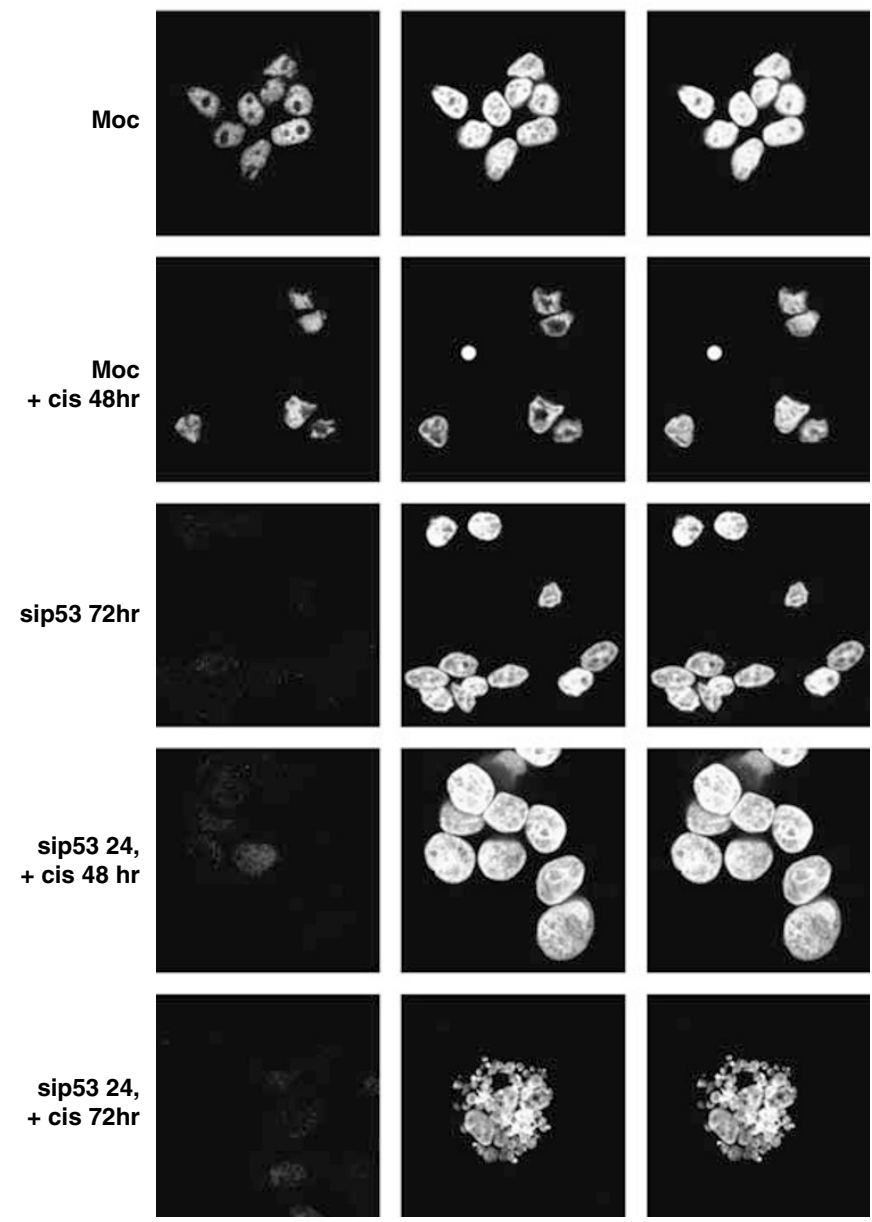

$20 \mu \mathrm{m}$

Figure 8 p53 silencing and Chk2 inhibition in Caov-4 cells induce mitotic catastrophe in response to cisplatin. Caov-4 cells $\left(10^{5}\right)$ were transfected with vehicle or wt p53 vector for 48,72 and $96 \mathrm{~h}$ prior to $24 \mathrm{~h}$ cisplatin treatment and harvested. (a) Cell lysates (100 $\mu \mathrm{g}$ ) were analyzed by western blot. siRNA silencing of p53 at the indicated time points is shown. Moc, scramble siRNA used as a control. G3PDH was used as a control for equal loading of the samples. (b) Changes in the nuclear morphology in untransfected, moc or p53 siRNA-transfected SKOV-3 cells treated with or without cisplatin up to $72 \mathrm{~h} \mathrm{(24} \mathrm{h} \mathrm{post-transfection).} \mathrm{Cells} \mathrm{were} \mathrm{stained} \mathrm{using} \mathrm{antibodies} \mathrm{directed}$ against p53. Co-staining of nuclei was performed using Hoechst. (c) Changes in the nuclear morphology in DBH pretreated (24 h) and treated with cisplatin Caov-4 cells for the indicated time points. Representative images of cells stained with Hoechst were visualized under fluorescence microscope. Bar $20 \mu \mathrm{m}$

Measurement of caspase activity. The measurement of cleaved fluorogenic caspase substrates (Peptide Institute, Osaka, Japan) was carried out as follows. Cells $\left(5 \times 10^{5}\right)$ were washed with ice-cold PBS, resuspended in $25 \mu \mathrm{l}$ of PBS and loaded on a microtiter plate. Next, fluorogenic substrates VDVAD-AMC $(50 \mu \mathrm{M})$, DEVD-AMC $(50 \mu \mathrm{M})$, LEHD-AMC $(50 \mu \mathrm{M})$ or IETD-AMC $(50 \mu \mathrm{M})$ dissolved in a standard reaction buffer (100 mM Hepes, $\mathrm{pH} 7.25,10 \%$ sucrose, $10 \mathrm{mM}$ DTT, $0.1 \%$ CHAPS) for VDVAD-AMC and LEHD-AMC or (100 mM MES, pH 6.5, 10\% polyethylene glycol, $10 \mathrm{mM}$ DTT, $0.1 \%$ CHAPS) for DEVD-AMC and IETD-AMC, were added to the wells. Cleavage of these substrates was monitored by AMC liberation in a Fluoroscan II plate reader (Labsystems) using $355 \mathrm{~nm}$ excitation and $460 \mathrm{~nm}$ emission wavelengths. Fluorescence units were converted to picomoles of AMC using a standard curve generated with free AMC. Data from triplicate samples were then analyzed by linear regression.
Gel electrophoresis and immunoblotting. Cell were harvested, washed in PBS and lysed for $30 \mathrm{~min}$ on ice in lysis buffer $(20 \mathrm{mM}$ Tris- $\mathrm{HCl}, \mathrm{pH}$ 8.0, $2 \mathrm{mM}$ EDTA, $138 \mathrm{mM} \mathrm{NaCl}, 10 \%$ glycerol, $1 \%$ Triton X-100 and $1 \times$ complete protease inhibitors (Roche Diagnostics). Cell extracts were centrifuged at $10 \times g$ for $8 \mathrm{~min}$ at $37^{\circ} \mathrm{C}$ to separate insoluble material, followed by determination of protein concentration using the BSA assay (Pierce). Equal amounts of protein from each sample were mixed with Laemmli's loading buffer, boiled for $5 \mathrm{~min}$ and subjected to SDS-PAGE at $130 \mathrm{~V}$ followed by electroblotting to nitrocellulose membranes for $2 \mathrm{~h}$ at $100 \mathrm{~V}$. Membranes were blocked for $1 \mathrm{~h}$ with $5 \%$ non-fat milk in PBS at room temperature and subsequently probed with the primary antibody of interest. Blots were revealed by $\mathrm{ECL}^{\mathrm{TM}}$ (Amersham Biosciences, Uppsala, Sweden).

Antibodies. Primary antibodies used in Western blotting, immunostaining and FACS were anti-p53 mAb, clone G59-12 (BD Biosciences); polyclonal anti-caspase-3 
a

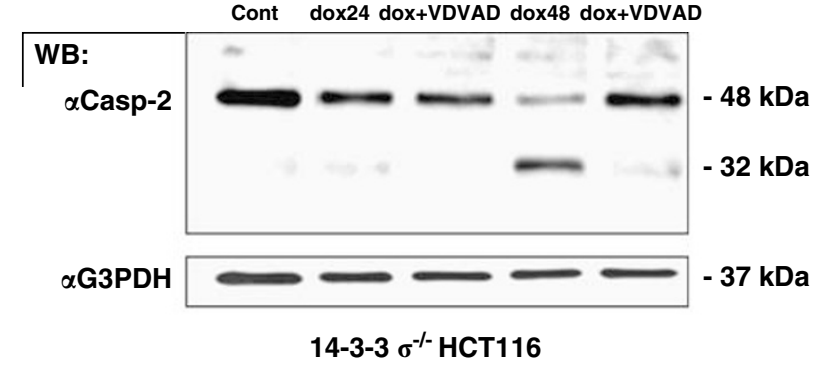

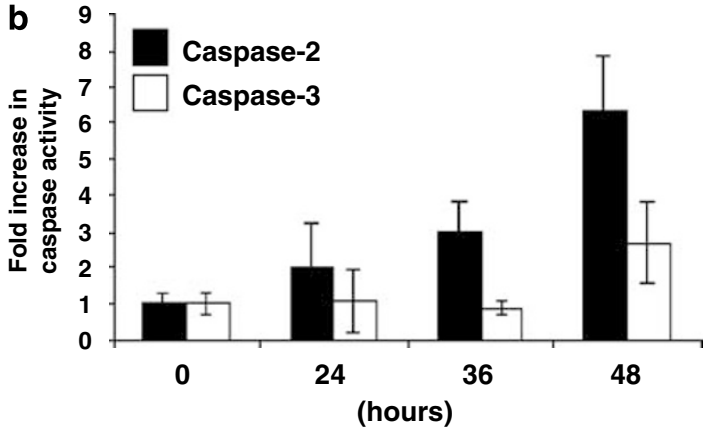

C

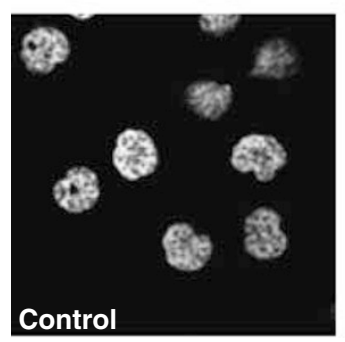

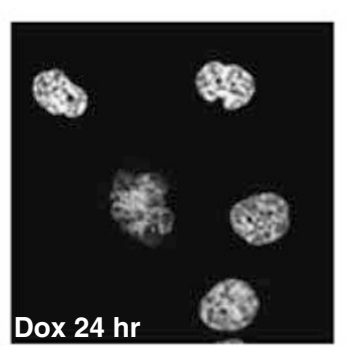

14-3-3 $\sigma^{-/-}$HCT116

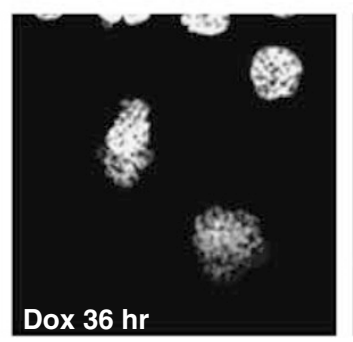

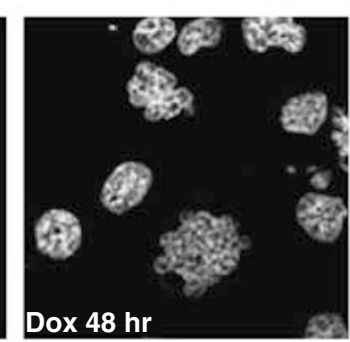

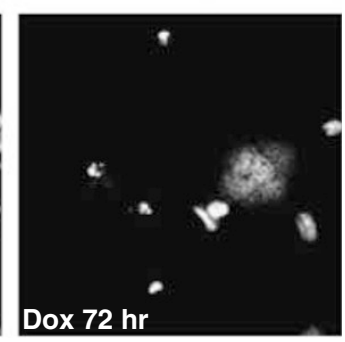

$\overline{20 \mu \mathrm{m}}$

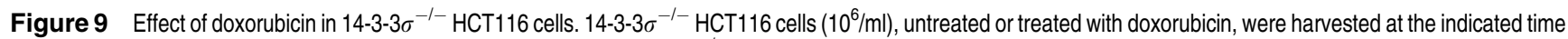
points and analyzed by western blot. (a) Immunoblot of caspase-2 in 14-3-3 $\sigma^{-1-}$ HCT116 cell lysates (100 $\mu \mathrm{g}$ ). Blots were re-probed for G3PDH to confirm an equal loading of the samples. (b) Enzyme activity was monitored by the release of AMC from VDVAD-AMC, fold increase in caspase-2 activity and DEVD-AMC, fold increase in caspase-3-like activity. Results are mean \pm S.E. $(n=3)$. (c) Changes in the nuclear morphology of 14-3-3 $\sigma^{-1-}$ HCT116 cells treated with doxorubicin at the indicated time points. Representative pictures of cells stained with Hoechst were obtained under fluorescence microscope. Bar $20 \mu \mathrm{m}$

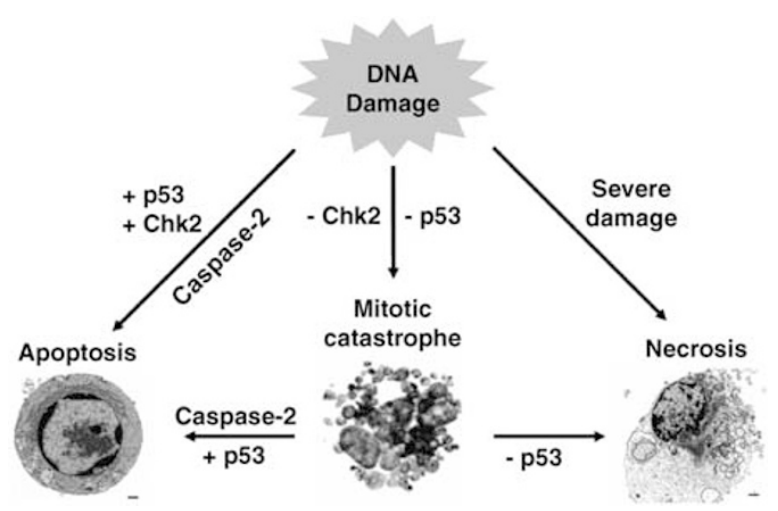

Figure 10 DNA damage induces different modes of cell death. Depending on the severity of DNA damage cells might die by apoptosis or necrosis. Functional p53 and caspase-2 are required for the apoptotic response. In the absence of functional p53 or cell cycle regulated proteins, cells upon DNA damage might undergo mitotic catastrophe. This process is caspase-2-independent and is followed by necrosis. In these cells, apoptotic functions could be restored by transient expression of wt p53. Hence, p53 appears to act as a switch between apoptosis and mitotic catastrophe followed by necrosis-like lysis. Inhibition of Chk2, and/or 14-3-3 $\sigma$ deficiency, sensitizes cells to undergo mitotic catastrophe upon treatment with DNA-damaging agents. However, apoptotic cell death seems to be the final outcome of this process

Ab (BD Biosciences); anti-cleaved caspase-3 mAb clone ASP175 (Cell Signaling); biotin-conjugated, polyclonal anti-active caspase-3 $\mathrm{Ab}$ (Pharmingen); anti-Bax mAb, clone 6A7 (BD Biosciences); polyclonal anti-caspase-9 Ab (BD Biosciences); polyclonal anti-caspase-8 Ab (BD Biosciences); anti-caspase-2 mAb, clone 35 (BD Biosciences); polyclonal anti-G3PDH Ab (Nordic Biosite, Täby, Sweden); anticytochrome $5 \mathrm{cmAb}$, clone 7H8.2C12 (BD Biosciences); anti-PIDD mAb, clone Anto-1 (Alexis Biochemicals), anti-phospho-histone H3 (Ser10) mAb, clone 6G3 (Cell
Signaling); anti-PARP mAb, clone 4C10-5 (BD Biosciences); polyclonal anti-Bid Ab (Cell Signaling); anti-AIF mAb, clone D-20 (Santa Cruz). All primary antibodies were diluted in PBS containing $1 \%$ bovine serum albumin, $0.05 \%$ Tween-20 and $0.1 \% \mathrm{NaN}_{3}$. Secondary antibodies were diluted in blocking buffer. Horseradishperoxidase-conjugated secondary antibodies were purchased from Pierce.

Cytofluorometric analysis. The distribution of cells in the sub- $\mathrm{G}_{1}, \mathrm{G}_{1}, \mathrm{~S}$ and $\mathrm{G}_{2} / \mathrm{M}$ cell cycle phases was determined by flow cytometry. Cells were harvested at $1 \times 10^{6} \mathrm{cells} / \mathrm{ml}$, washed in PBS, fixed in ice-cold $70 \%$ ethanol for $30 \mathrm{~min}$ and stained with PI solution $(50 \mu \mathrm{g} \mathrm{Pl} / \mathrm{ml}, 0.1 \%(\mathrm{w} / \mathrm{w})$ Triton X-100 and $0.1 \%(\mathrm{w} / \mathrm{w})$ $\mathrm{Na}$-citrate in PBS) in the presence of RNase $A\left(0.5 \mathrm{mg} / \mathrm{ml}\right.$ at $4^{\circ} \mathrm{C}$ overnight). Flow cytometric analysis was carried out using a FACScan flow cytometer equipped with CellQuest software (Becton Dickinson, San Jose, CA, USA).

Mitochondrial cytochrome $c$ release. Cells $\left(1 \times 10^{6}\right)$ treated as indicated in Figures $2 \mathrm{c}$ and $3 \mathrm{~b}$ were washed in ice-cold PBS, resuspended in $100 \mu$ lof buffer (5 mM Tris- $\mathrm{HCl}, \mathrm{pH} 7.4,50 \mathrm{mM} \mathrm{KCl}, 5 \mathrm{mM} \mathrm{MgCl}, 1 \mathrm{mM}$ EGTA, $5 \mathrm{mM}$ succinate, $1 \mathrm{mM} \mathrm{KH}_{2} \mathrm{PO}_{4}, 140 \mathrm{mM}$ mannitol) and permeabilized with digitonin $(0.01 \%)$ for $5 \mathrm{~min}$ at RT. Mitochondria and nuclei were removed from the soluble cytosolic fraction by centrifugation at $16000 \times g$ for $5 \mathrm{~min}$. Mitochondrial pellets and supernatants containing released cytochrome $c$ were subsequently separated in SDS-PAGE and analyzed by immunoblotting.

siRNA methodology. Silencing of caspase-2 and p53 mRNA was achieved by transfection of 21-nt RNA duplexes. Transfection of anti-caspase-2 (ONTARGETplus SMARTpool L-003465-00-0005, Dharmacon) and control (sense-ugagaaugugaugcgcguc-tt, EirX) siRNA were carried out using the LipofectAMINE 2000 reagent (Invitrogen) according to the manufacturer's instructions and using $10 \mathrm{nmol}$ of double-stranded siRNA. Transfection of antip53 (SI02655170 HP validated; Qiagen, Hilden, Germany) siRNA was carried out using the HiPerFect transfection (Qiagen) reagent according to the manufacturer's instructions and using $5 \mathrm{nmol}$ of double-stranded siRNA. The level of caspase-2 and p53 expression in targeted cells was monitored by SDS-PAGE. Protein 
downregulation was confirmed at $24 \mathrm{~h}$ for caspase- 2 and $48 \mathrm{~h}$ for $\mathrm{p} 53$ after transfection and lasted for up to 5 days

RT-PCR. Total RNA was isolated from induced and non-induced cells by taking advantage of the RNAeasy mini kit (Qiagen). RNA quality was controlled by separation of $18 \mathrm{~S}$ and $28 \mathrm{~S}$ ribosomal RNA in denaturing agarose gel electrophoresis and by visualization through ethidium bromide staining. For firststrand cDNA synthesis, the RevertAid ${ }^{\mathrm{TM}}$ M-MuL V RT enzyme (Fermentas) was used in combination with an oligo(dT)18 primer, and according to the instructions of the manufacturer. The PCR was performed using the Platinum ${ }^{\circledR} \mathrm{Pfx}$ DNA polymerase system (Invitrogen) and the following specific primers (Thermo Hybaid, Middlesex, UK): PIDD (forward primer (fp), ACCAGTGGCAGCCCTCATTC; reverse primer (rp), TGACCGGTTGGAAGCTG), p53 (fp, ACCAGGGCAGCTACGGTTTC; rp, CCTGGGCATCCTTGAGTTCC) and G3PDH (fp, CCTGGCCAAGGTCATCCATG; rp, TGAGGTCCACCCTGTTG). The conditions for all PCR reactions were as follows: $94^{\circ} \mathrm{C}$ for $1 \mathrm{~min}$ (hot start) followed by $95^{\circ} \mathrm{C}$ for $15 \mathrm{~s}, 60^{\circ} \mathrm{C}$ for $30 \mathrm{~s}$ and $68^{\circ} \mathrm{C}$ for $50 \mathrm{~s}$. Samples were removed every five cycle to ensure exponential product growth. PCR yield was analyzed on a $2 \%$ agarose gel.

Acknowledgements. We thank Dr. Bert Vogelstein (The Johns Hopkins School of Medicine, Baltimore, USA) for providing $14-3-3 \sigma^{-\gamma_{-}}$HCT116 cells and plasmid-encoding wild-type p53 and Margareta Sandström for technical assistance. This study was supported by grants from the Swedish Science Foundation (K200631X-02471-39-3 and 2006-24035-41265-48), Swedish (06-0279) and Stockholm (061491) Cancer Societies and the EC-FP-6 (Oncodeath and Chemores) and EC-FP-7 (APO-SYS)

1. Sancar A, Lindsey-Boltz LA, Unsal-Kacmaz K, Linn S. Molecular mechanisms of mammalian DNA repair and the DNA damage checkpoints. Annu Rev Biochem 2004; 73: $39-85$.

2. Shieh SY, Ikeda M, Taya Y, Prives C. DNA damage-induced phosphorylation of p53 alleviates inhibition by MDM2. Cell 1997; 91: 325-334.

3. Vogelstein B, Lane D, Levine AJ. Surfing the p53 network. Nature 2000; 408: 307-310.

4. Bunz F, Dutriaux A, Lengauer C, Waldman T, Zhou S, Brown JP et al. Requirement for p53 and p21 to sustain G2 arrest after DNA damage. Science 1998; 282: 1497-1501.

5. Chan TA, Hermeking $H$, Lengauer $C$, Kinzler KW, Vogelstein B. 14-3-3Sigma is required to prevent mitotic catastrophe after DNA damage. Nature 1999; 401: 616-620.

6. Miyashita T, Reed JC. Tumor suppressor $\mathrm{p} 53$ is a direct transcriptional activator of the human bax gene. Cell 1995; 80: 293-299.

7. Nakano K, Vousden KH. PUMA, a novel proapoptotic gene, is induced by p53. Mol Cell 2001; 7: 683-694.

8. Tinel A, Janssens S, Lippens S, Cuenin S, Logette E, Jaccard B et al. Autoproteolysis of PIDD marks the bifurcation between pro-death caspase-2 and pro-survival NF-kappaB pathway. EMBO J 2007; 26: 197-208.

9. Lin Y, Ma W, Benchimol S. Pidd, a new death-domain-containing protein, is induced by p53 and promotes apoptosis. Nat Genet 2000; 26: 122-127.

10. Tinel A, Tschopp J. The PIDDosome, a protein complex implicated in activation of caspase2 in response to genotoxic stress. Science 2004; 304: 843-846.

11. Guo Y, Srinivasula SM, Druilhe A, Fernandes-Alnemri T, Alnemri ES. Caspase-2 induces apoptosis by releasing proapoptotic proteins from mitochondria. J Biol Chem 2002; 277 $13430-13437$.

12. Lassus $P$, Opitz-Araya $X$, Lazebnik $Y$. Requirement for caspase-2 in stress-induced apoptosis before mitochondrial permeabilization. Science 2002; 297: 1352-1354.

13. Robertson JD, Enoksson M, Suomela M, Zhivotovsky B, Orrenius S. Caspase-2 acts upstream of mitochondria to promote cytochrome $c$ release during etoposide-induced apoptosis. J Biol Chem 2002; 277: 29803-29809.

14. Vakifahmetoglu $\mathrm{H}$, Olsson M, Orrenius S, Zhivotovsky B. Functional connection between p53 and caspase-2 is essential for apoptosis induced by DNA damage. Oncogene 2006; 25: 5683-5692.

15. Jonathan EC, Bernhard EJ, McKenna WG. How does radiation kill cells? Curr Opin Chem Biol 1999; 3: 77-83.

16. Heald R, McLoughlin M, McKeon F. Human wee1 maintains mitotic timing by protecting the nucleus from cytoplasmically activated Cdc2 kinase. Cell 1993; 74: 463-474.
17. Castedo M, Perfettini JL, Roumier T, Valent A, Raslova $\mathrm{H}$, Yakushijin $\mathrm{K}$ et al. Mitotic catastrophe constitutes a special case of apoptosis whose suppression entails aneuploidy. Oncogene 2004; 23: 4362-4370.

18. Roninson IB, Broude EV, Chang BD. If not apoptosis, then what? Treatment-induced senescence and mitotic catastrophe in tumor cells. Drug Resist Updat 2001; 4: 303-313.

19. Lock RB Stribinskiene L. Dual modes of death induced by etoposide in human epithelia tumor cells allow Bcl-2 to inhibit apoptosis without affecting clonogenic survival. Cance Res 1996; 56: 4006-4012.

20. Eltabbakh GH, Awtrey CS. Current treatment for ovarian cancer. Expert Opin Pharmacother 2001; 2: 109-124

21. Bunz F, Hwang PM, Torrance C, Waldman T, Zhang Y, Dillehay L et al. Disruption of p53 in human cancer cells alters the responses to therapeutic agents. J Clin Invest 1999; 104 263-269.

22. Paroni G, Henderson C, Schneider C, Brancolini C. Caspase-2 can trigger cytochrome $C$ release and apoptosis from the nucleus. J Biol Chem 2002; 277: 15147-15161.

23. Hamroun D, Kato S, Ishioka C, Claustres M, Beroud C, Soussi T. The UMD TP53 database and website: update and revisions. Hum Mutat 2006; 27: 14-20.

24. Castedo M, Perfettini JL, Roumier T, Yakushijin K, Horne D, Medema R et al. The cell cycle checkpoint kinase Chk2 is a negative regulator of mitotic catastrophe. Oncogene 2004; 23 4353-4361.

25. Mansilla S, Priebe W, Portugal J. Mitotic catastrophe results in cell death by caspasedependent and caspase-independent mechanisms. Cell Cycle 2006; 5: 53-60.

26. Colussi PA, Harvey NL, Kumar S. Prodomain-dependent nuclear localization of the caspase-2 (Nedd2) precursor. A novel function for a caspase prodomain. $J$ Biol Chem 1998; 273: 24535-24542.

27. Mancini M, Machamer CE, Roy S, Nicholson DW, Thornberry NA, Casciola-Rosen LA et al. Caspase-2 is localized at the Golgi complex and cleaves golgin-160 during apoptosis. J Cell Biol 2000; 149: 603-612.

28. Ren J, Shi M, Liu R, Yang QH, Johnson T, Skarnes WC et al. The Birc6 (Bruce) gene regulates p53 and the mitochondrial pathway of apoptosis and is essential for mouse embryonic development. Proc Natl Acad Sci USA 2005; 102: 565-570.

29. van Loo G, Saelens X, Matthijssens F, Schotte P, Beyaert R, Declercq W et al. Caspases are not localized in mitochondria during life or death. Cell Death Differ 2002; 9: 1207-1211.

30. Zhivotovsky B, Samali A, Gahm A, Orrenius S. Caspases: their intracellular localization and translocation during apoptosis. Cell Death Differ 1999; 6: 644-651.

31. De Feudis P, Debernardis D, Beccaglia P, Valenti M, Graniela Sire E, Arzani D et al. DDPinduced cytotoxicity is not influenced by p53 in nine human ovarian cancer cell lines with different p53 status. Br J Cancer 1997; 76: 474-479.

32. Debernardis D, Sire EG, De Feudis P, Vikhanskaya F, Valenti M, Russo P et al. p53 status does not affect sensitivity of human ovarian cancer cell lines to paclitaxel. Cancer Res 1997; 57: 870-874.

33. Lamkanfi M, D'Hondt K, Vande Walle L, van Gurp M, Denecker G, Demeulemeester J et al. A novel caspase-2 complex containing TRAF2 and RIP1. J Biol Chem 2005; 280 6923-6932.

34. Chan TA, Hwang PM, Hermeking H, Kinzler KW, Vogelstein B. Cooperative effects of genes controlling the G(2)/M checkpoint. Genes Dev 2000; 14: 1584-1588.

35. Meek DW. The role of p53 in the response to mitotic spindle damage. Pathol Biol (Paris) 2000; 48: 246-254

36. Tao W, South VJ, Zhang Y, Davide JP, Farrell L, Kohl NE et al. Induction of apoptosis by an inhibitor of the mitotic kinesin KSP requires both activation of the spindle assembly checkpoint and mitotic slippage. Cancer Cell 2005; 8: 49-59.

37. Chen JG, Yang CP, Cammer M, Horwitz SB. Gene expression and mitotic exit induced by microtubule-stabilizing drugs. Cancer Res 2003; 63: 7891-7899.

38. Castedo M, Coquelle A, Vivet S, Vitale I, Kauffmann A, Dessen P et al. Apoptosis regulation in tetraploid cancer cells. EMBO J 2006; 25: 2584-2595.

39. Demarcq C, Bunch RT, Creswell D, Eastman A. The role of cell cycle progression in cisplatin-induced apoptosis in Chinese hamster ovary cells. Cell Growth Differ 1994; 5 983-993.

40. Jordan MA, Wendell K, Gardiner S, Derry WB, Copp H, Wilson L. Mitotic block induced in HeLa cells by low concentrations of paclitaxel (Taxol) results in abnormal mitotic exit and apoptotic cell death. Cancer Res 1996; 56: 816-825.

41. Waldman T, Lengauer C, Kinzler KW, Vogelstein B. Uncoupling of S phase and mitosis induced by anticancer agents in cells lacking p21. Nature 1996; 381: 713-716.

42. Nitta M, Kobayashi $\mathrm{O}$, Honda S, Hirota $\mathrm{T}$, Kuninaka $\mathrm{S}$, Marumoto $\mathrm{T}$ et al. Spindle checkpoint function is required for mitotic catastrophe induced by DNA-damaging agents. Oncogene 2004; 23: 6548-6558.

43. Chu K, Teele N, Dewey MW, Albright N, Dewey WC. Computerized video time lapse study of cell cycle delay and arrest, mitotic catastrophe, apoptosis and clonogenic survival in irradiated 14-3-3sigma and CDKN1A (p21) knockout cell lines. Radiat Res 2004; 162 270-286. 